\title{
Impact of nutrient availability on the trophic strategies of the planktonic protist communities in a disturbed Mediterranean coastal lagoon
}

\author{
Leruste Amandine 1,2, Garrido Marie 3, Malet Nathalie 4, Bec Beatrice 2, De Wit Rutger 2, \\ Cecchi Philippe ${ }^{2,5}$, Pasqualini Vanina ${ }^{1}$, *
}

1 UMR SPE CNRS/UMS Stella Mare CNRS, Université de Corse, 20250, Corte, France

2 MARBEC, Univ Montpellier, CNRS, Ifremer, IRD, Montpellier, France

${ }^{3}$ Environmental Agency of Corsica, 7 Avenue Jean Nicoli, 20250, Corte, France

4 Ifremer, Laboratoire Environnement Ressources Provence-Azur-Corse (LER/PAC), Station de Bastia, Z.I. Furiani, Immeuble Agostini, 20600, Bastia, France

${ }^{5}$ Centre de Recherches Océanologiques, CRO, Abidjan, Ivory Coast

*Corresponding author : Vanina Pasqualini, email address : pasqualini v@univ-corse.fr

\begin{abstract}
:
The impact of changes in nitrogen $(\mathrm{N})$ and phosphorus $(\mathrm{P})$ availability on the trophic strategies of planktonic protists was evaluated in a disturbed Mediterranean lagoon (Biguglia lagoon, France) using short-term bioassays. Natural communities were collected in three periods, i.e., autumn, spring and summer, to address the influence of the different environmental conditions. The responses of autotrophic plankton communities to experimentally induced $\mathrm{N}$ and/or $\mathrm{P}$ limitations were assessed as changes in chlorophyll a ( $\mathrm{Chl} \mathrm{a)} \mathrm{concentrations} \mathrm{and} \mathrm{in} \mathrm{the} \mathrm{abundances} \mathrm{of} \mathrm{potentially} \mathrm{mixotrophic} \mathrm{protists} \mathrm{taxa.} \mathrm{We}$ observed blooms (>105 cells I-1) of nanoflagellates in autumn, and of phycocyanin-rich picocyanobacteria in summer. Communities showed a co-limitation by $\mathrm{N}$ and $\mathrm{P}$ at the three sampling periods, despite high N:P ratios in autumn and spring. The high abundances of potentially mixotrophic dinoflagellates during these periods suggest the involvement of alternative trophic pathways for their maintenance in the lagoon. After bioassay incubations using different nutrient enrichment treatments, we often observed reduced abundances of mixotrophic protists containing $\mathrm{Chl}$ a with a concomitant increased abundance of protists without $\mathrm{Chl}$ a. This indicates a loss of chloroplasts and photoautotrophic abilities in protists cells, possibly reflecting a shift towards heterotrophy that could be sustained by phagotrophy.
\end{abstract}

Keywords : Growth rate, Dinoflagellates, Nutrient limitation, Mixotrophy 
In the last few decades, eutrophication upon nutrient over-enrichment has dramatically altered the functioning of many coastal waters (Boesch, 2002; Cloern, 2001). Coastal lagoons are particularly vulnerable to this threat due to their confinement from the marine water that leads to reduced water turnover and nutrient accumulation. De-eutrophication or reoligotrophication of these semi-enclosed ecosystems by reducing nutrient over-enrichment is a challenging issue for managers and scientific communities because eutrophication alters the services provided by these ecosystems. Indeed, nutrient over-enrichment may result in significant environmental disturbances (e.g. hypoxia and harmful algal blooms) that cause mass mortality in the whole food web.

To fully understand the impact of coastal lagoon eutrophication and de-eutrophication, the effect of nutrient availability must be evaluated at the different scales of the trophic web, particularly autotrophic plankton that quickly responds to nutrient availability changes and constitutes the basis of food webs (Boesch, 2002; Schramm, 1999). For instance, reduction of inorganic nitrogen $(\mathrm{N})$ and/or phosphorus $(\mathrm{P})$ load could lead to drastic changes in the community composition, in favor of organisms that can functionally adapt and thrive despite the increasing nutrient limitation. In this respect, strictly autotrophic plankton and potentially mixotrophic protists need to be considered together. Mixotrophic protists, also known as mixoplankton, contain chloroplasts with chlorophyll $a(\mathrm{Chl} a)$ and can be autotrophic when performing photosynthesis and heterotrophic by phagotrophy (Mitra et al., 2016). Several mixotrophic protists possess their own chloroplasts, while others are heterotrophic protists that have the capacity to acquire chloroplasts from phototrophic preys (Mitra et al., 2016). Some mixotrophic protists can thus lose chloroplasts and $\mathrm{Chl} a$ and become operational heterotrophic organisms. We use the term "potential mixotroph protists" to include all i) Chl $a$-containing 
protists belonging to species with known heterotrophic capacities, and ii) heterotrophic protists of species known to be capable of hosting a chloroplast and of autotrophy (Flynn et al., 2018; Mitra et al., 2016). Mixotrophic organisms have been reported to be more successful than strict heterotrophic or strict autotrophic species in coastal water ecosystems under nutrient-limiting conditions, and where increased runoff of nutrients and organic matter promotes high N:P ratios (Leles et al., 2018). Blooms of potentially harmful algal species with mixotrophic abilities have been increasingly observed in several coastal lagoons following the reduction of nutrients inputs (Collos et al., 2009; Leruste et al., 2016; Yamamoto, 2003). This community composition modification can lead to changes in the interactions between nutrient stocks and the different organisms in the community, and between organisms, particularly concerning competition and predation (Flynn and Mitra, 2009). The overall structure and dynamics of food webs are greatly affected by these changes that can alter the ecosystem functioning, for example through the occurrence of mixotrophic harmful algal blooms (Burkholder et al., 2008; Leles et al., 2018; Yamamoto, 2003).

For decades, Biguglia lagoon, the largest coastal lagoon in Corsica (France), has been experiencing an important eutrophication process, mainly linked to the development of agricultural activities on its watershed. This degradation intensified since the seventies, with the densification of human populations due to the increasing urbanization of the whole Biguglia catchment and also summer tourism. Significant changes in the composition of the primary producer communities have been documented, particularly a net reduction of the aquatic angiosperm cover (Pasqualini et al., 2017). Since 2009, hydrological management interventions have been implemented to increase water fluxes and reduce the confinement of Biguglia lagoon. Nevertheless, nutrient input must be reduced to strengthen these management efforts and to support the lagoon restoration (Pasqualini et al., 2017). To plan future actions for improving the lagoon ecological state, it is important to understand how the protist communities might 
physiologically and behaviorally respond to nutrient limitation. Indeed, in Biguglia lagoon, blooms of potentially mixotrophic dinoflagellates have been increasingly observed after the modification of the lagoon hydrology in 2009 (Cecchi et al., 2016; Garrido et al., 2016; Leruste et al., 2019b). The environmental causes of these blooms need to be identified to avoid management actions that might lead to potentially harmful algal blooms produced by mixotrophic dinoflagellates species, such as Prorocentrum cordatum (Ostenfeld) J.D. Dodge, 1975, formerly known as Prorocentrum minimum (Pavillard, 1916) J. Schiller, 1933.

Therefore, the aim of this study in the Biguglia coastal lagoon (Corsica) was to investigate the potential impact of changes in $\mathrm{N}$ and $\mathrm{P}$ availability on the trophic responses of planktonic protist communities, focusing on strictly autotrophic and potentially mixotrophic species. We focused on two particular objectives: (i) determining whether the local communities preferentially used $\mathrm{N}$ or $\mathrm{P}$ resources (internal, external and regenerated pools) to thrive in conditions of nutrient limitation; (ii) testing whether experimentally induced $\mathrm{N}$ and/or P limitation promotes the use of mixotrophic strategies by protists, particularly dinoflagellates. We hypothesized that co-limitation by $\mathrm{N}$ and $\mathrm{P}$ induced a development of potentially mixotrophic dinoflagellates suggesting the involvement of alternative trophic pathways for their maintenance in the lagoon. The key questions to be addressed are: (i) do planktonic protist communities vary among seasons? (ii) are there variations of trophic strategies for $\mathrm{N}$ or $\mathrm{P}$ resources among seasons? (iii) do these mixotrophic strategies play a significant role in the development of potentially harmful bloom in the lagoons?

\section{Materials and Methods}

Study site 
Biguglia lagoon $\left(42^{\circ} 36^{\prime} \mathrm{N}\right.$; $\left.9^{\circ} 28^{\prime} \mathrm{E}\right)$ is a shallow brackish coastal lagoon $\left(14.5 \mathrm{~km}^{2}\right.$, average depth $1.2 \mathrm{~m}$ ), separated from the Tyrrhenian Sea by a sandy beach barrier (Fig. 1). This choked lagoon (sensu Kjerfve, 1994) is connected to the sea by a long, narrow and shallow

114 natural inlet at the north end $(1.5 \mathrm{~km})$. The inlet morphology and its natural inclination to silt 115 up limit the marine water input and lead to a long water residence time ranging from several 116 days near the sea inlet to several weeks or months in the southern basin (Mouillot et al., 2000; 117 Pasqualini et al., 2017). Freshwater inputs (mainly from sewage plants, several rivers, and 118 pumping stations draining the agricultural plain) dominate the water budget of Biguglia lagoon

119 (Fig. 1). These inputs are directly controlled by the inter-annual and inter-seasonal climatic 120 variability and they drastically shape the lagoon salinity. Salinity steeply decreases from the 121 North to the South of the lagoon, because of the artificial freshwater inputs from the Golo River 122 that is connected to the lagoon through the Fossone canal in the South (Garrido et al., 2016). 123 Consequently, Biguglia lagoon displays a highly variable hydrological functioning which 124 affects salinity and nutrient inputs, directly influencing the phytoplankton community structure 125 and composition (Garrido et al., 2016; Lafabrie et al., 2013). This seasonal variability generally 126 determines three hydrological periods characterized by differences in nutrient origin and 127 availability, and in phytoplankton biomass, size class structure and photosynthetic performance 128 (Cecchi et al., 2016; Garrido et al., 2016).

Since the 1980s, increasing nutrient inputs from the watershed has gradually 130 eutrophicated Biguglia lagoon. This anthropogenic pressure is especially high during the 131 touristic summer period (Lafabrie et al., 2013). The lagoon sometimes presents higher nutrient 132 concentrations in the water column $\left(\mathrm{NH}_{4}, \mathrm{NO}_{2}, \mathrm{NO}_{3}, \mathrm{DIN}, \mathrm{Si}, \mathrm{TN}\right)$ compared with other 133 Mediterranean lagoons (Orsoni et al., 2001; Souchu et al., 2010). This phenomenon is enhanced 134 by the reduced exchanges with the sea. Compared with other Mediterranean coastal lagoons, 135 the sediment compartment displays a silting with high nutrient concentrations (total nitrogen 
136

and total phosphorus) and organic matter content that reflect the lagoon eutrophication (Souchu et al., 2010). Moreover, the southern basin of the lagoon is more eutrophicated than the northern basin (Garrido et al., 2016).

\section{Sampling procedures}

Water samples were collected in two stations representatives of the northern (NB) and the southern basins (SB) (Fig. 1, 42 $38^{\prime} 12^{\prime \prime N}, 9^{\circ} 27^{\prime} 15^{\prime \prime} \mathrm{E}$ and $42^{\circ} 35^{\prime} 00^{\prime \prime} \mathrm{N}, 9^{\circ} 29^{\prime} 18^{\prime \prime} \mathrm{E}$, respectively). Experiments for two stations were carried out in autumn 2013 (26/27 November and 4/5 December), spring 2014 (2/3 and 7/8 April), and summer 2014 (9/10 and 11/12 September). At each sampling station, sub-surface salinity, temperature, turbidity and percentage of dissolved oxygen (DO) were measured with a multi-parameter Water Quality Probe (YSI® 6600 V2-2). At each station, 70 L of water were sampled at sub-surface $(20 \mathrm{~cm}$ depth) and kept in the dark. All samples were pre-filtered through a $1000 \mu \mathrm{m}$ mesh to remove larger debris but not the zooplankton and larger phytoplankton cells (Collos et al., 2005). At the laboratory, water samples were immediately stored at $-20^{\circ} \mathrm{C}$ after homogenization. Sampling time for filtration and storage was within one hour. Measures of $\mathrm{NH}_{4}^{+}, \mathrm{PO}_{4}{ }^{3-}, \mathrm{NO}_{3}{ }^{-}$, $\mathrm{NO}_{2}^{-}, \mathrm{TN}$, and TP concentrations $(\mu \mathrm{M})$ were performed on duplicates of $80 \mathrm{~mL}$ previously filtered $(0.7 \mu \mathrm{m})$ with Whatman GF/F glass fiber filters (Aminot and Chaussepied, 1983). For calculating the Redfield ratio (DIN:DIP), DIN values corresponded to the sum of the concentrations of the different dissolved inorganic nitrogen forms $\left(\mathrm{NH}_{4}{ }^{+}, \mathrm{NO}_{3}{ }^{-}\right.$and $\left.\mathrm{NO}_{2}{ }^{-}\right)$, and DIP values corresponded to the concentration of dissolved reactive inorganic phosphorus $\left(\mathrm{PO}_{4}{ }^{3-}\right.$ $57 \quad)$ 
161 photoautotrophic plankton biomass (Neveux and Lantoine, 1993). Size fractioning of water samples with nylon filter meshes allowed estimating the biomasses of micro- $(>20 \mu \mathrm{m})$, nano-

163 (between 5 and $20 \mu \mathrm{m}$ in size), and ultraphytoplankton $(<5 \mu \mathrm{m}$ in size) according to the 164 protocol described in Leruste et al. (2019b).

The taxonomic composition of the phytoplankton communities was analyzed by optical 166 microscopy for cells $>5 \mu \mathrm{m}$, and by flow cytometry for cells $<5 \mu \mathrm{m}$, as described by Leruste et al. (2018). Identification of the phytoplankton communities was done using a Zeiss Axiolab microscope, at $\mathrm{x} 400$ or x600 depending on phytoplankton cell size, after sedimentation 169 (Utermöhl, 1958). At least 200 cells per sample were counted to obtain a relevant assessment 170 of the assemblage. Taxonomic resolution was realized at species level whenever possible 171 (Bourrelly, 1990; Tomas, 1997a, b; Bérard-Therriault et al., 1999; Loir, 2004; Bellinger and 172 Sigee, 2015), and taxonomy was verified using several databases such as the World Register of 173 Marine Species (http://www.marinespecies.org/, databases available online). Abundances of 174 picocyanobacteria, autotrophic picoeukaryotes, and ultraphytoplankton individuals were 175 estimated using a FACSCalibur flow cytometer (Becton-Dickinson), fitted with a $15 \mathrm{~mW}$ argon 176 laser (488 $\mathrm{nm}$ excitation). For sample processing, the sheath fluid was prepared from filtered 177 (pore size $0.2 \mu \mathrm{m}$ ) artificial seawater $(\mathrm{NaCl})$ whose salinity was adjusted to that of the samples 178 ( \pm 2 units) in order to avoid alterations of refractive indices of the cells and changes in the 179 measured Forward Side Scatter. Two protocols have been used depending on cell size. Sample 180 acquisition was done at a flow rate of 25 to $30 \mu \mathrm{L} \mathrm{min}{ }^{-1}$. Samples were diluted when events 181 reached $1000 \mathrm{~s}^{-1}$. The two eukaryotic groups were distinguished on the basis of optical 182 properties including FSC, related to cell size, and red fluorescence emissions (FL3), a proxy 183 for Chl a-content. Among picocyanobacteria, phycoerythrin-rich and phycocyanin-rich 
populations were identified and distinguished by their orange and/or red fluorescence emissions using beads for size calibration, but they were not identified at a more precise taxonomic level.

Experimental procedure to induce and evaluate phytoplankton nutrient limitation

At the three sampling periods, dilution experiments using the «all minus one» technique and dilution experiments with a full enrichment (FE) were performed to assess the physiological $\mathrm{N}$ and $\mathrm{P}$ limitation of autotrophic plankton communities in Biguglia lagoon (Andersen et al., 1991; Landry et al., 1998). For a detailed description of the protocol, see Leruste et al. (2019b). For each sample, three series of five dilutions $(9,17,43,74$ and 100\%) were prepared by dilution with water sampled at the site and filtered on $0.2 \mu \mathrm{m}$. The different dilutions were then incubated in different enrichment conditions, according to Andersen et al. (1991). The FE condition consisted of adding DIN and $\mathrm{PO}_{4}{ }^{3-}$ at final concentrations of $20 \mu \mathrm{M}$ and $0.8 \mu \mathrm{M}$, respectively. For each of the five dilutions, the first series was incubated with the FE, the second with FE minus N (-N), and the third with FE minus P (-P). Duplicates were performed for the different treatments, i.e. $\mathrm{FE},-\mathrm{N}$ and $-\mathrm{P}$, and in triplicate for the water sampled at the beginning of the experiment (see section 'Trophic mode of potentially mixotrophic taxa' hereafter). $\mathrm{N}$ was supplied as nitrate and/or ammonium, depending on the season. For the April 2014 samples, N was supplied as nitrate ( $20 \mu \mathrm{M}$ final concentration), on the basis of the assumption that nitrate inputs from watershed leaching represented the main $\mathrm{N}$ source in that period. For the September 2014 samples, $\mathrm{N}$ was supplied as ammonium ( $20 \mu \mathrm{M}$ final concentration), assuming that this

204 should have been the predominant form provided by the sediments as an internal source related 205 to the remineralization of organic matter (Collos et al., 2003; Cecchi et al., 2016). For the 206 November-December 2013 samples, $\mathrm{N}$ was supplied in both forms (10 $\mu \mathrm{M}$ each) because in 207 this period, temperatures can be sufficiently high to allow ammonium regeneration from the 208 sediments. Moreover, flash floods could bring nitrates from the watershed (Cecchi et al., 2016). 
All samples, including two bottles without enrichment (WE) for each sample, were incubated

210 simultaneously in Biguglia lagoon (in situ temperature and light conditions) at $30 \mathrm{~cm}$ depth for

$21124 \mathrm{~h}$. In the end, 32 bottles of $1 \mathrm{~L}$ are used, i.e. 30 bottles for the dilutions with enrichment and

2122 bottles for the control (100\% water sample without enrichment).

After $24 \mathrm{~h}$ incubation, the changes of total and size-fractionated Chl $a$ in each bottle were used to calculate the apparent growth rate $k(x)$ of autotrophic plankton at each dilution $x$. The relationship between the apparent growth rate and the dilution factor $x$ allowed calculating the maximal growth rate $\mu_{\max }$ and the mortality rate $g$. All rates were expressed on a per day basis $\left(\mathrm{d}^{-1}\right)$. In -N and -P treatments, the mean growth rates $\mu_{-\mathrm{N}}$ and $\mu_{\text {-P }}$ were estimated as follows: $\mu_{-\mathrm{N}}=g+k_{-\mathrm{N}}$ and $\mu_{-\mathrm{P}}=g+k_{\text {-P. }}$ (Andersen et al., 1991). The $g: \mu_{\max }$ ratio gave indications about the potential biomass transfer to higher trophic levels $(g: \mu>1)$ and about biomass accumulation $(g: \mu<1)($ Calbet and Landry, 2004).

Trophic mode of potentially mixotrophic taxa

The trophic mode of taxa that could be mixotrophic according to the literature was investigated at the two stations and for the three periods before and after incubation in the different treatments (WE, FE, $-\mathrm{N}$ and $-\mathrm{P}$ ) (undiluted samples). The analysis focused on 226 dinoflagellates, because most autotrophic dinoflagellates display phagocytic activity, and on autotrophic Euglenophyceae that are commonly observed in eutrophicated brackish waters and benefit from the high amounts of organic matter through their phagocytic activities (Stoecker, 1999; Willey et al., 1988). Triplicates of $250 \mathrm{~mL}$ of water samples fixed in glutaraldehyde ( $0.4 \%$ final concentration) and one sample per bottle at T24 (two bottles per treatment) were 231 stored at $4^{\circ} \mathrm{C}$ in the dark before analysis. Epifluorescence microscopy was used to identify cells showing Chl $a$ red fluorescence and to distinguish strictly heterotrophic organisms from those 233 capable of autotrophy at sampling time (Leruste et al., 2018; Seoane et al., 2011). More 
234 precisely for nanoflagellates, samples were stained with DAPI (Di Aminido Phenyl lndol) for

235 fifteen minutes in the dark and counted under an epifluorescence microscope. For 236 dinoflagellates, samples were counted directly under an optical microscope with or without 237 light filter.

Type of limitation

The "all minus one" experiment targeted the type of resource limitation of the total 241 phytoplankton and of the three size classes at the two stations and for the three periods. These 242 limitations were described using interaction plots representing the phytoplankton communities' 243 response (biomass increase) to factorial addition of $\mathrm{N}$ and $\mathrm{P}$ resources, with one line 244 representing $\mathrm{N}$ addition (without enrichment - enrichment minus $\mathrm{P}$ ), the other representing $\mathrm{P}$ 245 addition (enrichment minus $\mathrm{N}$ - full enrichment) (Harpole et al., 2011). The Y-axis represents 246 the biomass responses to the factorial addition of $\mathrm{N}$ and/or $\mathrm{P}$ relative to the bottles without 247 enrichment. The trends of these plots allow hypothesizing about the co-limitation type 248 (simultaneous, independent, serial and synergistic limitation), the negative response, and the 249 absence of response to nutrient addition (Harpole et al., 2011).

Contributing nutrient resources under experimentally-induced $\mathrm{N}$ and $\mathrm{P}$ limitations

Three potential nutrient sources were considered for phytoplankton growth during experimentally-induced nutrient limitations: (1) external source, including the nutrients dissolved in the water at the beginning of incubation; (2) internal nutrient pools present in cells at the start of incubation; (3) nutrients supplied by recycling through grazing, such as excretion, egestion and 'sloppy feeding' (i.e., release of organic matter during physical phytoplankton cell

257 breakage) (Andersen et al., 1991). In this study, their relative contributions to the biomass production during incubation were estimated using Eq. (2): 
260 Where $k(x)$ is the apparent phytoplankton growth rate at dilution $x$, and $K_{E}, K_{I}$, and $K_{R}$ are the 261 potential production coefficients of the three different nutrient pools. These coefficients 262 represent the relative yields of external, internal and remineralized nutrients, respectively. The 263 values of $K_{E}, K_{I}$, and $K_{R}$ were then obtained by multiple linear regression, with $x$ and $x^{-1}$ as 264 independent variables and $\exp (k(x) \mathrm{t})-1$ as the dependent variable. Equations were fitted with 265 the "Imer" function of the "Ime4" library (Bates et al., 2015), and model selection was based 266 on parsimony using the small-sample corrected Akaike's information criterion (Burnham and 267 Anderson, 2004) and the 'dredge' function of the MuMIn package (Bartón, 2013). We used 268 equation models proposed in the cited literature and modelized them on R. We used the MuMin 269 package for model selection by AICc (see Leruste et al., 2019a).

271 Statistical analysis and interpretation Statistical analyses were performed using R (R Core Team, 2013). The effects of the

273 four treatments on Chl $a$ concentrations and the abundances of potentially mixotrophic taxa 274 were assessed using parametric or non-parametric analyses of variance according to the data. 275 Parametric multifactorial variance analyses using 'anova.lm' function (Chambers, 1992) were 276 assessed when data fulfilled the conditions of application (normal distribution, 277 homoscedasticity and independence of residuals). When significant effects were observed, 278 Tukey posthoc tests using 'TukeyHSD' function were used to determine significant differences 279 in pairwise comparisons. If conditions of application were not fulfilled, logarithm 280 transformation were tested, and then in last option, non-parametric variance analyses were 281 assessed using 'kruskal test' and posthoc 'kruskalmc' test of the 'pgirmess' package 282 (Giraudoux, 2013). 
As detailed below, 'Imer' function from the 'Ime4' library (version 1.1-10, Bates et al., 2015), 'dredge' function of the 'MuMIn' package (Bartón, 2013) were used to explore the growth rate and limiting nutrient characteristics of the studied communities. concentration between the beginning and the end of the $24 \mathrm{~h}$ incubation (WE, FE, $-\mathrm{N}$ and $-\mathrm{P}$ ).

\section{Results}

Environmental variables and autotrophic plankton community composition

The environmental conditions and nutrient concentrations measured before the dilution experiments (T0) were very different according to the sampling period (autumn, spring and summer). Salinity was more variable at the northern station (NB) (from 2 in spring to 10.9 in summer) than at the southern station (SB) (from 6 in spring and summer, to 6.1 in autumn). The dissolved oxygen (DO) percentage was always more elevated at NB (from $97.0 \%$ in summer to $113 \%$ in spring) than at SB (from $86.2 \%$ in summer to $101.5 \%$ in autumn). Conversely, turbidity was lower at $\mathrm{NB}$ (from 0.8 in spring to 2.9 in autumn) than at $\mathrm{SB}$ (from 4.6 in spring to 16.8 in autumn). Temperature was lowest in autumn $\left(8^{\circ} \mathrm{C}\right)$ and highest in summer (average $25^{\circ} \mathrm{C}$ ). Nutrient concentrations and phytoplankton biomasses in the water column at T0 showed

302 the highest $\mathrm{PO}_{4}{ }^{3-}$ values in autumn at both stations (Table 1). The ratios of dissolved inorganic 303 nitrogen to dissolved inorganic phosphorus (DIN:DIP ratios) were much higher than the 304 Redfield ratio (i.e., 16:1) in samples collected in autumn and spring (the two wet seasons), while they were lower in summer (Table 1). These elevated DIN:DIP ratios were caused by high $\mathrm{NO}_{3}{ }^{-}$ 
stations for the three sampling periods, except at SB in autumn when it peaked at $20.6 \mu \mathrm{g}^{-1}$

308 (Table 1).

The percentages of micro-, nano- and ultraphytoplankton biomasses are presented in

Table 1, and the taxonomic composition of the phytoplankton communities in the two stations

311 at the three sampling periods is summarized in Figure 2. Ultraphytoplankton represented the

312 highest biomass fraction at both stations and at all sampling times (until $88.0 \%$ at SB in

313 summer). The proportions of micro- and nanophytoplankton were highest at NB in autumn and 314 at SB in spring (Table 1).

In autumn, nanophytoplankton represented the highest proportion of the total biomass

$316(39.8 \%)$ at NB. This was caused by a bloom of Dictyochophyceae Apedinella radians

317 (Lohmann) P.H. Campbell, $1973\left(1.3 \times 10^{6}\right.$ cells. $L^{-1}$, representing $100 \%$ of the

318 Dictyochophyceae abundance) and Dinoflagellate Prorocentrum cordatum $\left(2.9 \times 10^{5}\right.$ cells.L ${ }^{-1}$,

319 representing $87.6 \%$ of the Dinoflagellates abundance) (Fig. 2). At SB, the community was

320 dominated by a bloom of Dinoflagellate Heterocapsa minima Pomroy, $1989\left(5.1\right.$ x $10^{6}$ cells.L $^{-}$

$321{ }^{1}$, representing $98.2 \%$ of the Dinoflagellates abundance), but also showed high abundance of

322 Dictyochophyceae Apedinella radians $\left(4.8 \times 10^{6}\right.$ cells. $\mathrm{L}^{-1}$, representing $99.9 \%$ of the

323 Dictyochophyceae abundance) and of the ciliate Mesodinium rubrum Lohmann, 1908 (2.3 x

$32410^{5}$ cells. $L^{-1}$ ). Picoeukaryotes and Cryptophyceae were also abundant (Fig. 2). In spring, the

325 community at NB was dominated by dinoflagellates with a bloom of $\mathrm{H}$. minima $\left(3.7 \times 10^{6}\right.$

326 cells. $\mathrm{L}^{-1}$, representing $97.7 \%$ of the Dinoflagellates abundance), and by diatoms $\left(3.1 \times 10^{6}\right.$

327 cells. $\mathrm{L}^{-1}$ ) (Fig. 2). Community in SB was dominated by a bloom of phycocyanin-rich

328 picocyanobacteria (PC-picocyanobacteria) and picoeukaryotes $\left(6.4 \times 10^{7}\right.$ cells. $\mathrm{L}^{-1}$ and $5.6 \times 10^{7}$

329 cells. $\mathrm{L}^{-1}$, respectively) (Fig. 2). M. rubrum was also abundant at this station $\left(1.6 \times 10^{5}\right.$ cells. $\mathrm{L}^{-}$

$330{ }^{1}$ ). In summer, ultraphytoplankton was dominant (more than $80 \%$ of the total biomass at both 
stations) due to a bloom of PC-picocyanobacteria $\left(9.4 \times 10^{8}\right.$ cells. $\mathrm{L}^{-1}$ in NB, $3.0 \times 10^{8}$ cells.L $\mathrm{L}^{-1}$ at SB) and picoeukaryotes $\left(6.5 \times 10^{7}\right.$ cells. $\mathrm{L}^{-1}$ in NB, $1.7 \times 10^{7}$ cells.L $\mathrm{L}^{-1}$ at SB) (Fig. 2).

At T0, potentially mixotrophic protists containing $\mathrm{Chl} a$ (+Chl $a$ protists) were significantly more abundant than those without $\mathrm{Chl} a$ (-Chl $a$ protists) in the communities of both stations at all sampling dates (Fig. 3). The abundances of the two size classes varied significantly between stations and sampling seasons (two-ways ANOVA, $p$-value <0.05).

At all sampling dates and at both stations, $+\mathrm{Chl} a$ protists between 10 and $20 \mu \mathrm{m}$ in size were mainly represented by $H$. minima, $P$. cordatum, and Heterocapsa niei (Loeblich III) Morrill \& Loeblich III, 1981 (Fig. 3A). Blooms of H. minima occurred at SB at the three sampling periods (from $1.1 \times 10^{5}$ cells. $\mathrm{L}^{-1}$ in spring to $3.7 \times 10^{6}$ cells. $\mathrm{L}^{-1}$ in autumn) and at NB in spring $\left(2.2 \times 10^{6}\right.$ cells. $\left.\mathrm{L}^{-1}\right)$, associated with high abundance of $H$. niei $\left(1.9 \times 10^{5}\right.$ cells. $\left.\mathrm{L}^{-1}\right)$. At NB in autumn and summer, protists $>10 \mu \mathrm{m}$ in size were dominated by $P$. cordatum $(1.7 \mathrm{x}$ $10^{5}$ cells. $\mathrm{L}^{-1}$ and $9.4 \times 10^{4}$ cells. $\mathrm{L}^{-1}$, respectively). At SB, the highest abundances and proportions of $+\mathrm{Chl} a>20 \mu \mathrm{m}$ in size in autumn and spring were caused by $M$. rubrum blooms (Fig. 3C). In summer, +Chl $a$ protists $>20 \mu \mathrm{m}$ in size included mainly Gymnodinium sp., Gonyaulax sp., and M. rubrum at both stations (Fig. 3C).

In both size classes, -Chl $a$ protists were low in numbers, and even not detected in spring at NB (Fig. 3B-D). H. minima and P. cordatum (10-20 $\mu \mathrm{m}$ size fraction) and Gyrodinium sp. and Gymnodinium sanguineum (>20 $\mu \mathrm{m}$ size fraction) were dominant in autumn and spring (Fig. 3B-D). In summer, Gymnodinium sp. was dominant at both fractions (Fig. 3B-D).

\section{Nutrient enrichment/limitation bioassays: abundance of potentially mixotrophic protists} The changes in total Chl $a$ concentration in undiluted water samples from the two stations after 24 hours of incubation (T24) with the four treatments (without enrichment, WE; 
full enrichment, FE; enrichment without $\mathrm{N}$, -N; and enrichment without $\mathrm{P},-\mathrm{P}$ ) are presented in

356 Fig. 4 as percent changes, i.e. $100 *(\mathrm{Chl} a$ T24 - Chl $a$ T0)/Chl $a$ т0.

The final added concentration of DIN was $20 \mu \mathrm{M}$, with different compositions used in

the three different seasons assuming a better simulation of the conditions prevailing during the season (i.e., 10/10, 20/0 and $0 / 20$ of $\mathrm{NO}_{3}{ }^{-} / \mathrm{NH}_{4}{ }^{+}$for autumn, spring and summer, respectively; see Methods). The FE enrichment did not always induce an increase of $\mathrm{Chl} a$ concentration

361 between T0 and T24 (Fig. 4). In autumn, Chl $a$ concentration was reduced by $32 \%$ at NB and by $23 \%$ at SB at T24 (Fig. 4A). In spring, Chl $a$ concentration significantly increased by $33 \%$ at NB, while it decreased by $10 \%$ at SB (Fig. 4B). Conversely, in summer, Chl $a$ concentration 364 significantly increased by more than three times at NB and four times at SB (non-parametric 365 ANOVAs and post-hoc Kruskal test, $p$-value <0.05) (Fig. 4C). In the $-\mathrm{P}$ enrichment, $\mathrm{Chl} a$ concentration at $\mathrm{SB}$ decreased after the $24 \mathrm{~h}$ incubation in autumn and spring, whereas at NB it increased in autumn (by 12\%) and decreased in spring (non-parametric ANOVA, p-value <0.05) (Fig. 4A-B). In summer, Chl a concentration increased by $150 \%$ at NB and by $350 \%$ at SB, respectively.

Analysis of the abundance variations of potentially mixotrophic protists $>10 \mu \mathrm{m}$ in size (+Chl a and $-\mathrm{Chl}$ a) between $\mathrm{T} 0$ and T24 (Fig. 5) revealed that after 24 hours, +Chl a protists between 10 and $20 \mu \mathrm{m}$ in size were generally more abundant than the larger $+\mathrm{Chl}$ a protists (> 375 treatment.

In autumn at $\mathrm{NB}$, only the abundance of $+\mathrm{Chl} a$ protists $>20 \mu \mathrm{m}$ in size was significantly 377 reduced by $61 \%$ in the $-\mathrm{P}$ enrichment (two-ways ANOVA, $p$-value <0.05, Fig. 5A). However, 378 abundance variations were very high in all incubation conditions and at all seasons. Moreover, 379 in the WE condition, the abundances of -Chl $a$ protists between 10 and $20 \mu \mathrm{m}$ in size were 
reduced by $81 \%$, and those $>20 \mu \mathrm{m}$ in size by $50 \%$ (Fig. 5A). At SB, the abundance of $+\mathrm{Chl} a$

381 protists (both size classes) was significantly decreased after the incubation with the WE treatment (from $38 \%$ for the 10 to $20 \mu \mathrm{m}$ in size to $68 \%$ for the $>20 \mu \mathrm{m}$ in size) (Fig. $5 \mathrm{~A}$ ).

Conversely, the abundance of -Chl $a$ protists between 10 and $20 \mu \mathrm{m}$ in size significantly increased in the WE, -N and -P enrichments (two-ways ANOVA, $p$-value <0.05) (Fig. 5A). Specifically, after incubation with the $-\mathrm{P}$ treatment, abundance of $-\mathrm{Chl} a$ protists between 10 and $20 \mu \mathrm{m}$ in size increased by $13550 \%$ and those $>20 \mu \mathrm{m}$ in size by $50 \%$ (Fig. 5A). In spring, the abundance of $+\mathrm{Chl} a$ protists between 10 and $20 \mu \mathrm{m}$ in size at NB significantly decreased after $24 \mathrm{~h}$ incubation with FE, -N and -P (two-ways ANOVA, $p$-value $<0.05)$ (Fig. 5B). Moreover, -Chl $a$ protists (both size classes) appeared after $24 \mathrm{~h}$ incubation with the four treatments. At SB, the abundance of $-\mathrm{Chl} a$ and $+\mathrm{Chl} a$ protists $>20 \mu \mathrm{m}$ in size

391 did not significantly change after $24 \mathrm{~h}$ incubation (all conditions), whereas abundance of $+\mathrm{Chl}$ $a$ protists between 10 and $20 \mu \mathrm{m}$ in size decreased upon incubation with the four treatments. Abundance of -Chl $a$ protists between 10 and $20 \mu \mathrm{m}$ in size decreased with the WE and FE treatments whereas it increased with $-\mathrm{N}$ and $-\mathrm{P}$ treatments (Fig. 5B).

In summer, protists abundance at NB was not significantly affected by any of the four experimental treatments (Fig. 5C), although $+\mathrm{Chl} a$ protists between 10 and $20 \mu \mathrm{m}$ in size increased by $12 \%$ (WE) and by $47 \%(-\mathrm{N})$, while $-\mathrm{Chl} a$ protists between 10 and $20 \mu \mathrm{m}$ in size decreased by $50 \%$ in the FE enrichment. At SB, the abundance of $+\mathrm{Chl} a$ protists between 10 and $20 \mu \mathrm{m}$ in size significantly increased by $151 \%$ with the FE and by $141 \%$ with the $-\mathrm{P}$

400 treatment (two-ways ANOVA, $p$-value <0.05) (Fig. 5C). The abundance of -Chl $a$ protists 401 between 10 and $20 \mu \mathrm{m}$ in size increased by $744 \%$ with the WE treatment, but this change was 402 not significant (Fig. 5C).

404 Nutrient enrichment/limitation bioassays: trophic strategy 

responses e.g. single $\mathrm{N}$ or P-limitation, negative response, absence of response, or differential co-limitation by $\mathrm{N}$ and $\mathrm{P}$. Analysis of the average responses to factorial addition of $\mathrm{N}$ and/or $\mathrm{P}$ (Fig. 6) confirmed that incubation with the FE (with $\mathrm{N}$ and $\mathrm{P}$ ) did not always lead to an increase of the phytoplankton biomass compared with the enrichments without $\mathrm{N}$ and/or P. For example, for the bioassay performed at NB in autumn, the total phytoplankton and the micro- and ultraphytoplankton biomasses were reduced upon exposure to FE compared with the absence of enrichment (Fig. 6A). As several 24h incubations led to biomass loss and to negative growth rates, we decided to focus only on the positive responses.

In autumn, only the size classes containing high abundances of potentially mixotrophic species showed positive growth rates with the four treatments. Specifically, at NB, nanophytoplankton displayed the highest growth rates upon incubation with $\mathrm{FE}$, $-\mathrm{N}$, and -P compared with WE, indicating a sub-additive, independent co-limitation by $\mathrm{N}$ and $\mathrm{P}$ (Fig. 6A). At SB, the growth of total phytoplankton, micro- and nanophytoplankton was stimulated by all the inability to calculate a positive $\mu_{0}$ and suggesting a strong nutrient limitation. For total phytoplankton and nanophytoplankton, the interaction plots highlighted a single N-limitation (Fig. 6A), whereas for ultraphytoplankton the higher growth rates with $-\mathrm{N}$ and $-\mathrm{P}$ compared with FE indicated an independent co-limitation by $\mathrm{N}$ and $\mathrm{P}$ (Fig. 6A). In spring, at NB, only nanophytoplankton that contained high abundances of potentially

425 mixotrophic $H$. minima dinoflagellates showed a positive response in the four treatments, 426 particularly with $-\mathrm{N}$ rather than WE, and with FE and -P, indicating a single $\mathrm{P}$ limitation (Fig. 427 6B). For the total phytoplankton and the microphytoplankton fraction, the three enrichments 428 allowed a release of the growth limitation observed without enrichment $\left(\mu_{0}<0\right)$. Total 429 phytoplankton also showed a single $\mathrm{P}$ limitation, while microphytoplankton displayed 
independent co-limitation by $\mathrm{N}$ and $\mathrm{P}$ (Fig. 6B). At SB, total phytoplankton showed a single N-

431 limitation, while nanophytoplankton was simultaneously co-limited by $\mathrm{N}$ and $\mathrm{P}$, and 432 ultraphytoplankton displayed a sub-additive independent co-limitation by N and P (Fig. 6B).

433 In summer, the responses of the phytoplankton communities to the different enrichments

434 indicated a strong nutrient limitation at both stations. At NB, total phytoplankton and 435 nanophytoplankton displayed a super-additive independent co-limitation by $\mathrm{N}$ and $\mathrm{P}$, while 436 microphytoplankton and ultraphytoplankton showed a serial limitation by N and P (Fig. 6C). 437 At SB, total phytoplankton showed an additive independent co-limitation by $\mathrm{N}$ and $\mathrm{P}$. As the 438 microphytoplankton biomass at T0 was too low to be estimated, its growth rate and limitation 439 could not be calculated. Nanophytoplankton displayed a serial limitation by $\mathrm{N}$ and $\mathrm{P}$, and 440 ultraphytoplankton was simultaneously co-limited by $\mathrm{N}$ and $\mathrm{P}$.

441 Analysis of the potential biomass production supported by internal, external and 442 recycled $\mathrm{N}$ and $\mathrm{P}$ pools reflects the percentage of their use by total phytoplankton. The three 443 size classes showed that overall, phytoplankton in Biguglia lagoon mainly used internal $\mathrm{N}$ and $444 \mathrm{P}$ resources to cope with the experimentally-induced limitations during the three periods 445 (negative coefficients were not taken into account; absence of bars in Fig. 7).

446 In autumn, phytoplankton at NB mainly used recycled $\mathrm{N}$ resources in conditions of $\mathrm{N}$ 447 limitation. However, micro- and nanophytoplankton mainly used internal $\mathrm{N}$ resources (Fig. 7). 448 At SB, phytoplankton used recycled and internal N pools, whereas the three fractions mainly 449 used internal N resources (Fig. 7). In P-limiting conditions, phytoplankton at NB used all three 450 P pools to cope with the P-limitation, while micro- and ultraphytoplankton only used recycled 451 P and nanophytoplankton its internal P resources (Fig. 7). At SB, each of the three size classes 452 of phytoplankton used internal P resources to cope with P limitation (Fig. 7). In spring, phytoplankton and the different fractions at both stations only used internal $\mathrm{N}$ 454 resources to cope with $\mathrm{N}$ limitation (Fig. 7). To cope with $\mathrm{P}$ limitation, total phytoplankton and 
nanophytoplankton at NB mainly used their internal P resources, while microphytoplankton

456 relied on recycled and external P resources (90\% and 10\%, respectively) (Fig. 7). At SB, total

457 phytoplankton and nanophytoplankton mainly used internal $\mathrm{P}$ resources to cope with $\mathrm{P}$ 458 limitation, and ultraphytoplankton external P pools (Fig. 7).

In summer, to cope with $\mathrm{N}$ limitation, total, nano- and ultraphytoplankton at NB mainly used the internal and external $\mathrm{N}$ pools, while microphytoplankton only used internal $\mathrm{N}$ resources (Fig. 7). At SB, total and ultraphytoplankton only used external $\mathrm{N}$ pools, and nanophytoplankton only internal $\mathrm{N}$ resources. To cope with $\mathrm{P}$ limitation, total, micro- and ultraphytoplankton at NB relied on internal N pools, and nanophytoplankton on all three pools

464 (55\% of internal, and $22 \%$ of recycled and external pools) (Fig. 7). At SB, total phytoplankton only used the internal P pool to cope with the experimentally-induced P limitation.

\section{Discussion}

Mediterranean coastal lagoons display a high diversity of ecosystem functioning, directly linked to the intrinsic seasonal variability and to anthropogenic pressures. These pressures affect the delivery of freshwater discharge and nutrient load that influence the composition and activity of planktonic primary producers (Paerl et al., 2014). Our experimental study focused on the functional responses of autotrophic plankton communities to nutrient availability changes, and on their adaptive strategies in adverse conditions.

In autumn, despite the high concentrations of dissolved inorganic nutrients (especially $477 \mathrm{NO}_{3}{ }^{-}$), autotrophic planktonic protists showed an independent co-limitation by $\mathrm{N}$ and $\mathrm{P}$. 478 However, because of the unbalanced N:P ratios (much higher than the Redfield ratio) caused 479 by the elevated DIN concentration we expected to a strong P limitation. Different reasons might 
explain the unexpected co-limitation. First, the ambient nutrient N:P ratio does not necessarily

481 reflect the actual concentration of available nutrients, because plankton communities may have 482 already consumed part of these nutrients (Leruste et al., 2016). Second, communities are composed of multiple species with different resource requirements, and specific adaptations to limiting resources. The Redfield ratio is a generalization and many species have different $\mathrm{N}: \mathrm{P}$ requirements. This niche differentiation can lead to species limited by different nutrients, causing a $\mathrm{N}$ and $\mathrm{P}$ co-limitation for the total community (Burson et al., 2016; Harpole et al., 2011). Moreover, as many factors affects nutrient limitation, subtle changes in nutrient supply, community composition, and biogeochemical cycling can modify the nutrient availability and thus the nutrient limitation (Paerl et al., 2014).

To cope with limiting resources, autotrophic plankton species can adjust their strategy of nutrient acquisition and uptake by using different pools of resources. Many planktonic groups (e.g., diatoms and dinoflagellates) can use their internal $\mathrm{N}$ and $\mathrm{P}$ reserves in response to nutrient depletion (Andersen et al., 1991). Indeed, the bioassay results for samples collected in autumn showed that internal $\mathrm{N}$ and $\mathrm{P}$ were the main resources used by autotrophic plankton of Biguglia lagoon. Moreover, dinoflagellates and flagellates, including potentially mixotrophic species, dominated the communities of the two stations. In addition, only the size classes containing high abundances of potentially mixotrophic species (i.e., nanophytoplankton at NB, micro- and nanophytoplankton at SB) showed positive growth rates after incubation with the 499 four treatments. The decreased abundance of potentially mixotrophic $+\mathrm{Chl} a$ protists, especially at SB 501 station, and the increase of -Chl $a$ protists highlight that several cells lost their Chl $a$ content 502 during the bioassay. This suggests that incubation with the four treatments strongly affected the health of these cells that lost their photosynthetic abilities. Alternatively, limiting conditions 504 could have induced phagotrophy rather than photosynthesis in H. minima and P. cordatum. 
505 Indeed, $\mathrm{N}$ and $\mathrm{P}$ limiting conditions can induce mixotrophy in some dinoflagellates species

506 (Johnson, 2015). Moreover, in the Seto Inland Sea of Japan, an increase of the TN:TP ratio 507 promoted blooms of potentially mixotrophic dinoflagellates, such as Alexandrium tamarense 508 and Gymnodinium catenatum that used dissolved organic $\mathrm{P}$ to cope with the increasing $\mathrm{P}$ 509 limitation (Yamamoto, 2003). Therefore, in our study, cells that lost Chl $a$ could have obtained 510 their nutrients from ingesting organic forms or preys. The absence of use of external or recycled 511 nutrient observed during experimentally induced $\mathrm{N}$ and $\mathrm{P}$ limitations supports this hypothesis, 512 and could explain the observed co-limitation by $\mathrm{N}$ and $\mathrm{P}$ rather than by $\mathrm{P}$ alone (Burson et al., 513 2016). In the presence of unbalanced $\mathrm{N}: \mathrm{P}$ ratios, potentially mixotrophic species might 514 outcompete strict autotrophic cells, although the latter have higher growth rate (Mitra et al., 515 2016). This could also explain the occurrence of dinoflagellate blooms, although 516 nanoflagellates (e.g., A. radians) and picoeukaryotes present in the community have higher 517 growth rates and higher affinity for dissolved inorganic nutrient uptake (Reynolds, 2006). The Chl $a$ concentration decrease after $24 \mathrm{~h}$ incubation observed in almost all treatments 519 suggests a strong limitation of autotrophic planktonic protist communities, and a strong 520 predation on these autotrophic organisms. The $g: \mu_{\max }$ ratio can be used as a proxy of primary 521 production consumed by species of higher trophic levels (Fig. 8) (Calbet and Landry, 2004). In 522 autumn, its value indicated a transfer of biomass to higher trophic levels $\left(g: \mu_{\max }>1\right)$ at both 523 stations. This high consumption of primary production may also corroborate the hypothesis of 524 the importance of the phagotrophic abilities of mixotrophic dinoflagellates species. Indeed, at 525 both stations, nanophytoplankton rich in $H$. minima and $P$. cordatum (two potentially 526 mixotrophic species) displayed $g: \mu_{\max }$ ratios $<1$, indicating that this fraction accumulated 527 biomass after incubation with FE. We could hypothesize that they used their phagotrophic 528 abilities because this size class did not rely on the external and recycled $\mathrm{N}$ and P pools. 
In spring, the community composition was different at the two stations, with a

530 dominance of nanoplanktonic dinoflagellates and diatoms at NB and of PC-picocyanobacteria

531 at SB. This difference of community composition could reflect contrasting environmental

532 characteristics between the two sub-basins, such as freshwater inputs (Leruste et al., 2019b).

533 Their functional responses to the nutrient availability also were different. The single $\mathrm{P}$

534 limitation of the total community and of the nanophytoplankton fraction at NB was coherent

535 with the high N:P ratio observed. This result could be explained by (i) the strong affinity of 536 diatoms for nitrate that was the main $\mathrm{N}$ form at the sampling time, and (ii) the potential use of 537 phagotrophy or osmotrophy by $H$. minima rather than strict photoautotrophy. As observed in 538 autumn, this hypothesis could also explain the decreased abundance of potentially mixotrophic $539+$ Chl $a$ protists during the bioassay, suggesting that the limited number of these less 540 competitive taxa, compared for example with diatoms, might have promoted the use of organic 541 nutrient resources. The $g: \mu_{\max }$ ratio for this period showed a difference between 542 ultraphytoplankton (mainly picoeukaryotes at NB and PC-picocyanobacteria at SB) that were 543 consumed by higher trophic level species $\left(g: \mu_{\max }>1\right)$, and nanophytoplankton that accumulated 544 biomass $\left(g: \mu_{\max }<1\right)$ (Fig. 8). This also supports the mixotrophy of nanophytoplankton that 545 probably grazed on ultraphytoplankton (Garrido et al., 2016). In spring at SB and in summer at both stations, communities were largely dominated by

547 blooming PC-picocyanobacteria (more than $10^{8}$ cells. $\mathrm{L}^{-1}$ ). The bloom of PC-picocyanobacteria 548 during summer suggests that internal nutrient loading from the sediments may play a critical 549 role in cyanobacterial bloom development (Glibert et al., 2010). In the SB community in spring, 550 only PC-picocyanobacteria used external P resources under the P-limiting conditions reflecting 551 their strong $\mathrm{P}$ uptake efficiency. This may explain why this community was co-limited by $\mathrm{N}$ 552 and $\mathrm{P}$ or limited only by $\mathrm{N}$ rather that by $\mathrm{P}$. Moreover, the ratio $g: \mu_{\max }<1$ for ultraphytoplankton 553 at both stations indicates that $\mathrm{NH}_{4}{ }^{+}$and $\mathrm{PO}_{4}{ }^{3-}$ enrichments led to biomass accumulation despite 
554 the potential high grazing pressure on this class size (Collos et al., 2009; Śliwińska-Wilczewska

555 et al., 2018) (Fig. 8). The dense bloom of PC-picocyanobacteria reduced oxygen availability, 556 increased water turbidity, and coincided with high abundances of Gonyaulax sp. $\left(10^{4}\right.$ cells.L $\left.\mathrm{L}^{-1}\right)$ 557 at both stations. As several mixotrophic species graze on the cyanobacterium Synechococcus $558 s p$., PC-picocyanobacteria blooms may have directly benefited to mixotrophic species that 559 could cope with the increased light limitation and nutrient depletion by consuming PC560 picocyanobacteria to sustain their carbon requirement (Collos et al., 2009; Flynn et al., 2018). Mixotrophy represents a metabolic duality that is difficult to characterize due to its complexity. However, recent studies have proposed to categorize mixotrophs in constitutive mixotrophs (CMs) with stable plastids, and non-constitutive mixotrophs (NCMs) that lack 564 plastids but can host endosymbiotic algae or steal plastids from their preys. As in our 565 experiments, all observed morphotypes and taxa included at least one fraction of + Chl $a$ cells, 566 they might be classified as strict photo-autotrophic organisms (PAs), or as CMs. They could 567 also correspond to one of the NCM categories (generalist, plastid specialist, or endosymbiotic 568 specialist) if they found enough preys to keep operating plastids during the $24 \mathrm{~h}$ incubation. 569 However, our results do not allow classifying them with certainty. For example, even species 570 that always contained $\mathrm{Chl} a$ could not be strictly classified as PAs or CMs. For instance, $M$. 571 rubrum and Dinophysis sp. cells all contained Chl $a$, but they correspond to plastid specialized 572 NCMs (Mitra et al., 2016). Moreover, in several taxa, such as $H$. minima, some cells lost their 573 Chl $a$ content during the incubation. These taxa (with + and -Chl $a$ cells) could correspond to 574 NCMs. Nevertheless, this is, to the best of our knowledge, the first report showing the potential 575 mixotrophic behavior of H. minima, although this adapting trophic regime has been observed 576 for other species of this genus (Leles et al., 2019; Millette et al., 2017). Defining the kind of 577 mixotrophy of these organisms is fundamental because this has important implications for the 578 whole community behavior. Indeed, each group displays different interactions and dynamics in 
the trophic food web. These contrasting mixotrophic strategies imply different ecological impacts through their need or removal of preys, and their competitiveness according to the resource availability. For example, belonging to the $\mathrm{CM}$ group would imply a higher competitiveness compared with NCMs, and the potential ability to cause important blooms in favorable conditions (Mitra et al., 2016).

\section{Conclusions}

One-time bioassays at three different seasons gave only a snapshot of the phytoplankton responses to nutrient availability in Biguglia lagoon. Nevertheless, they validated our 589 hypothesis stated in the introduction, namely that co-limitation by $\mathrm{N}$ and $\mathrm{P}$ induced a 590 development of potentially mixotrophic dinoflagellates, suggesting the involvement of 591 alternative trophic pathways for their maintenance in the lagoon. We document (i) that the 592 diversity of planktonic protist communities and (ii) that the use strategies for $\mathrm{N}$ or $\mathrm{P}$ resources 593 varied among seasons, and (iii) that these mixotrophic strategies play a significant role in the 594 development of potentially harmful bloom in the lagoons.

595 Our experiments have increased knowledge about the seasonal variability of these responses. We particularly highlighted two bloom types that have adverse effects on Biguglia

597 lagoon health. The bloom of PC-picocyanobacteria during summer indicate that internal 598 nutrient loading from the sediments play a critical role in cyanobacterial bloom development in 599 Biguglia lagoon. This emphasizes the importance of reducing nutrient stocks to prevent blooms 600 of potentially harmful cyanobacteria and other species, such as mixotrophic species favored by 601 high prey abundance. In autumn and spring, the high abundance of potentially mixotrophic dinoflagellates 603 brings questions about the choice of ecological restoration measures to mitigate the risk of 
604 potentially harmful bloom in these seasons. As mixotrophic species can use both inorganic and 605 organic nutrient resources, a reduction of these nutrients is necessary. However, a reduction of 606 prey abundance can further favor mixotrophic and potentially harmful species that benefit from 607 the increase of inorganic nutrient limitation to outcompete the strict photo-autotrophic and 608 phago-heterotrophic species.

This study raises many questions that need closer consideration. Our results suggest that the abundance of mixotrophic dinoflagellate species is increasing in Biguglia lagoon due to several synergistic factors, such as unbalanced $\mathrm{N}: \mathrm{P}$ ratio due to high $\mathrm{N}$ inputs, internal nutrient stocks, and the seasonal presence of high prey abundance. Therefore, we need to identify the

613 driver(s) of mixotrophy for these species, and their relationship with organic nutrient stocks 614 and their potential preys. Identifying the mixotroph category of the observed taxa is also essential, because their role in the ecosystem functioning would also be different.

Acknowledgments Amandine Leruste was supported in 2018 by a Postdoctoral fellowship of the University of Corsica Pasquale Paoli (SPE CNRS 6134 Laboratory and UMS Stella Mare) and the Collectivity of Corsica, and from 2013 to 2016 by a $\mathrm{PhD}$ fellowship of the Doctoral

621 School at the University of Montpellier. This work has been financed by Biguglia lagoon nature reserve, the Collectivity of Corsica and the University of Corsica Pasquale Paoli, that authors

623 are grateful for their cooperation. This work was (co) funded by the Labex DRIIHM, French 624 programme "Investissements d'Avenir" (ANR-11-LABX-0010) which is managed by the 625 ANR. We thank the Ifremer station of Bastia and the UMS Stella Mare for technical support 626 and help during the experiments. Thanks are extended to everyone who participated in the 627 experiments. Authors also thank the Microbex platform of the MARBEC UMR that provided 628 microscopy and imaging equipment, and particularly Cécile Roques that provided technical 
629 support for microscopic analyses. All authors have approved the final article.

630 


\section{References}

632 Aminot, A. \& M.C. Chaussepied, 1983. Manuel des analyses chimiques en milieu marin. Brest: CNEXO.

Andersen, T., A. Schartau \& E. Paasche, 1991. Quantifying external and internal nitrogen and phosphorus pools, as well as nitrogen and phosphorus supplied through remineralization, in coastal marine plankton by means of a dilution technique. Marine Ecology Progress Series 69: 67-80. doi:10.3354/meps069067.

Bartón, K. \& M. Mu, 2013. In: Multi-modal inference. Model selection and model averaging based on information criteria (AICc and alike). Httpcranr-Proj.

Bates, D., M. Mächler, B. Bolker \& S. Walker, 2015. Fitting Linear Mixed-Effects Models Using lme4. Journal of Statistical Software 67. doi:10.18637/jss.v067.i01.

Bellinger, E.G. \& D.C. Sigee, 2015. Freshwater algae: identification, enumeration and use as bioindicators. John Wiley \& Sons Inc, Hoboken.

Bérard-Therriault, L., M. Poulin \& L. Bossé, 1999. Guide d'identification du phytoplancton marin de l'estuaire et du golfe du Saint-Laurent incluant certains protozoaires. Canadian Special Publication of Fisheries and Aquatic Sciences 128. NRC Research Press.

647 Bourrelly, P., 1990. Algues vertes : algues d'eau douce. Tome 1. Boubée.

648 Boesch, D.F., 2002. Challenges and opportunities for science in reducing nutrient overenrichment of coastal ecosystems. Estuaries 25: 886-900. doi:10.1007/BF02804914.

650 Burkholder, J.M., P.M. Glibert \& H.M. Skelton, 2008. Mixotrophy, a major mode of nutrition

651 for harmful algal species in eutrophic waters. Harmful Algae 8: 77-93. 652 doi:10.1016/j.hal.2008.08.010.

653 Burnham, K.P. \& D.R. Anderson, 2004. Model Selection and Multimodel Inference. New York, $654 \quad$ NY: Springer New York.

655 Burson, A, M. Stomp, L. Akil, C.P.D. Brussaard \& J. Huisman, 2016. Unbalanced reduction of 
nutrient loads has created an offshore gradient from phosphorus to nitrogen limitation in the North Sea. Limnology and Oceanography 61: 869-888. doi:10.1002/lno.10257.

Calbet, A \& M.R. Landry, 2004. Phytoplankton growth, microzooplankton grazing, and carbon cycling in marine systems. Limnology and Oceanography 49: 51-57.

660 Cecchi, P., M. Garrido, Y. Collos \& V. Pasqualini, 2016. Water flux management and 661 phytoplankton communities in a Mediterranean coastal lagoon. Part II: Mixotrophy of 662 dinoflagellates as an adaptive strategy? Marine Pollution Bulletin 108: 120-133. doi:10.1016/j.marpolbul.2016.04.041.

664 Chambers, J.M., 1992. Linear models. Chapter 4 of Statistical Models in S eds J.M. Chambers and T.J. Hastie, Wadsworth \& Brooks/Cole.

666 Cloern, J.E., 2001. Our evolving conceptual model of the coastal eutrophication problem. 667 Marine Ecology Progress Series 210: 223-253. doi:10.3354/meps210223.

668 Collos, Y., B. Bec, C. Jauzein, E. Abadie, T. Laugier, J. Lautier, A. Pastoureaud, P. Souchu \& A. Vaquer, 2009. Oligotrophication and emergence of picocyanobacteria and a toxic dinoflagellate in Thau lagoon, southern France. Journal of Sea Research 61: 68-75. doi:10.1016/j.seares.2008.05.008.

672 Collos, Y., J. Husseini-Ratrema, B. Bec, A. Vaquer, T.L. Hoai, C. Rougier, V. Pons, P. \& P. Souchu, 2005. Pheopigment dynamics, zooplankton grazing rates and the autumnal ammonium peak in a Mediterranean lagoon. Hydrobiologia 550: 83-93. doi:10.1007/s10750-005-4365-1.

676 Collos, Y., A. Vaquer, B. Bibent, P. Souchu, G. Slawyk \& N. Garcia, 2003. Response of coastal 677 phytoplankton to ammonium and nitrate pulses: seasonal variations of nitrogen uptake and regeneration. Aquatic Ecology 37: 227-236. doi:10.1023/A:1025881323812.

679 Flynn, K.J. \& A. Mitra, 2009. Building the "perfect beast": modelling mixotrophic plankton. $680 \quad$ Journal of Plankton Research 31: 965-992. doi:10.1093/plankt/fbp044. 
Flynn, K.J., A Mitra, P.M. Glibert \& J.M. Burkholder, 2018. Mixotrophy in Harmful Algal Blooms: By Whom, on Whom, When, Why, and What Next. In: Glibert P.M., Berdalet E., Burford M.A., Pitcher G.C., Zhou M., editors. Global Ecology and Oceanography. Harmful Algal Blooms, Cham: Springer International Publishing: pp 113-132. doi:10.1007/978-3319-70069-4_7.

Garrido, M., P. Cecchi, Y. Collos, S. Agostini \& V. Pasqualini, 2016. Water flux management and phytoplankton communities in a Mediterranean coastal lagoon. Part I: How to promote dinoflagellate dominance? Marine Pollution Bulletin 104: 139-152. doi:10.1016/j.marpolbul.2016.01.049.

690 Giraudoux, P., 2013. Pgirmess: data analysis in ecology. R package version 1.5.

691 Glibert, Boyer, J.N., Heil, C., Madden, C.J., Sturgis, B. \& Wazniak, C.S., 2010. Coastal 692 Lagoons: Critical Habitats of Environmental Change. CRC Press, Boca Raton, FL.

Harpole, W.S., J.T. Ngai, E.E. Cleland, E.W. Seabloom, E.T. Borer, M.E.S. Bracken, J.J. Elser,

694 D.S. Gruner, H. Hillebrand, J.B. Shurin \& J.E. Smith, 2011. Nutrient co-limitation of 695 primary producer communities. Ecology Letters 14: 852-862. doi:10.1111/j.1461$696 \quad$ 0248.2011.01651.x.

697 Johnson, M.D., 2015. Inducible Mixotrophy in the Dinoflagellate Prorocentrum minimum. 698 Journal of Eukaryotic Microbiololy 62: 431-443. doi:10.1111/jeu.12198.

699 Lafabrie, C., M. Garrido, C. Leboulanger, P. Cecchi, G. Grégori, V. Pasqualini \& O. Pringault, 700 2013. Impact of contaminated-sediment resuspension on phytoplankton in the Biguglia 701 lagoon (Corsica, Mediterranean Sea). Estuarine Coastal and Shelf Sciences 130: 70-80. 702 doi:10.1016/j.ecss.2013.06.025.

703 Landry, M.R., S.L. Brown, L. Campbell, J. Constantinou \& H. Liu, 1998. Spatial patterns in 704 phytoplankton growth and microzooplankton grazing in the Arabian Sea during monsoon 705 forcing. Deep-Sea Research part II 45: 2353-2368. doi:10.1016/s0967-0645(98)00074-5. 
Leles, S.G., L. Polimene, J. Bruggeman, J. Blackford, S. Ciavatta, A. Mitra \& K.J. Flynn, 2018.

707 Modelling mixotrophic functional diversity and implications for ecosystem function. Journal of Plankton Research 40(6): 627-642. doi:10.1093/plankt/fby044.

Leruste, A, N. Malet, D. Munaron, V. Derolez, E. Hatey, Y. Collos, R. De Wit \& B. Bec, 2016. First steps of ecological restoration in Mediterranean lagoons: Shifts in phytoplankton communities. Estuarine

Coastal an

Shelf Sciences 180: $\quad 190-203$. doi:10.1016/j.ecss.2016.06.029.

713

714

715

Leruste, A., S. Villéger, N. Malet, R. De Wit \& B. Bec, 2018. Complementarity of the multidimensional functional and the taxonomic approaches to study phytoplankton communities in three Mediterranean coastal lagoons of different trophic status. Hydrobiologia 815: 207-227. doi:10.1007/s10750-018-3565-4.

Leruste, A., F. Guilhaumon, R. De Wit, N. Malet, Y. Collos \& B. Bec, 2019a. Phytoplankton strategies to exploit nutrients in coastal lagoons with different eutrophication status and involved in a re-oligotrophication process. Aquatic Microbial Ecology 83: 131-146. doi: 10.3354/ame01906.

Leruste, A, V. Pasqualini, M. Garrido, N. Malet, R. De Wit \& B. Bec, 2019b. Physiological and behavioral responses of phytoplankton communities to nutrient availability in a disturbed Mediterranean coastal lagoon. Estuarine, Coastal and Shelf Science 219: 176-188. doi: 10.1016/j.ecss.2019.02.014.

Loir, M., 2004. Guide des diatomées : Plus de 200 micro-algues silicieuses photographiées. Delachaux \& Niestlé, Paris.

Millette, N.C., J.J. Pierson, A. Aceves \& D.K. Stoecker, 2017. Mixotrophy in Heterocapsa rotundata: A mechanism for dominating the winter phytoplankton. Limnology and Oceanography 62: 836-845. doi:10.1002/lno.10470.

Mitra, A., K.J. Flynn, U. Tillmann, J.A. Raven, D. Caron, D.K. Stoecker, F. Not, P.J. Hansen, 
G. Hallegraeff, R. Sanders, S. Wilken, G. McManus, M. Johnson, P. Pitta, S. Våge, T. Berge, A. Calbet, F. Thingstad, H.J. Jeong, J. Burkholder, P.M. Glibert, E. Graneli \& V. Lundgren, 2016. Defining Planktonic Protist Functional Groups on Mechanisms for Energy and Nutrient Acquisition: Incorporation of Diverse Mixotrophic Strategies. Protist 167: 106120. doi:10.1016/j.protis.2016.01.003.

Mouillot, D., A. Titeux, C. Migon, V. Sandroni, J.P. Frodello \& D. Viale, 2000. Anthropogenic influences on a mediterranean Nature Reserve: modelling and forecasting. Environ Modelling Assessment 5: 185-192. doi:10.1023/A:1011533811237.

Neveux J. \& F. Lantoine, 1993. Spectrofluorometric assay of chlorophylls and phaeopigments using the least squares approximation technique. Deep Sea Research Part I 40: 1747-1765. doi:10.1016/0967-0637(93)90030-7.

Orsoni, V., P. Souchu \& D. Sauzade, 2001. Caractérisation de l'état d'eutrophisation des trois principaux étangs corses (Biguglia, Diana et Urbino), et proposition de renforcement de leur surveillance. Rapport final, Ifremer.

Paerl, H.W., N.S. Hall, B.L. Peierls \& K.L. Rossignol, 2014. Evolving Paradigms and Challenges in Estuarine and Coastal Eutrophication Dynamics in a Culturally and Climatically Stressed World. Estuaries Coasts 37: 243-258. doi:10.1007/s12237-014-9773$\mathrm{x}$.

749 Pasqualini, V., V. Derolez, M. Garrido, V. Orsoni, Y. Baldi, S. Etourneau, V. Leoni, P. 750 Rébillout, T. Laugier, P. Souchu \& N. Malet, 2017. Spatiotemporal dynamics of submerged 751 macrophyte status and watershed exploitation in a Mediterranean coastal lagoon: 752 Understanding critical factors in ecosystem degradation and restoration. Ecological $753 \quad$ Engineering 102: 1-14. doi:10.1016/j.ecoleng.2017.01.027.

754 R Core Team, 2013. A language and environment for statistical computing. R Foundation for 755 Statistical Computing,Vienna, Austria. URL http://www.R-project.org/. 
756 Reynolds, C.S., 2006. Ecology of phytoplankton. Cambridge; New York: Cambridge $757 \quad$ University Press.

758 Schramm, W., 1999. Factors influencing seaweed responses to eutrophication: some results 759 from EU-project EUMAC. Journal of Applied Phycology 11: 69-78. 760 doi:10.1023/A:1008076026792.

761 Seoane, S., M. Garmendia, M. Revilla, A. Borja, J. Franco, E. Orive \& V. Valencia, 2011. 762 Phytoplankton pigments and epifluorescence microscopy as tools for ecological status 763 assessment in coastal and estuarine waters, within the Water Framework Directive. Marine 764 Pollution Bulletin 62: 1484-1497. doi:10.1016/j.marpolbul.2011.04.010.

765 Śliwińska-Wilczewska, S., J. Maculewicz, A. Barreiro Felpeto \& A. Latała, 2018. Allelopathic 766 and Bloom-Forming Picocyanobacteria in a Changing World. Toxins 10(1): 48. doi:10.3390/toxins 10010048 .

Souchu, P., B. Bec, V.H. Smith, T. Laugier, A. Fiandrino, L. Benau, V. Orsoni, Y. Collos, \& A. Vaquer, 2010. Patterns in nutrient limitation and chlorophyll a along an anthropogenic eutrophication gradient in French Mediterranean coastal lagoons. Canadian Journal of Fish Aquatic Sciences 67: 743-753. doi:10.1139/F10-018.

Stoecker, D.K., 1999. Mixotrophy among dinoflagellates. Journal of Eukaryotic Microbiology 46: 397-401. doi:10.1111/j.1550-7408.1999.tb04619.x. $320-321$.

Tomas, C.R., 1997b. Identifying Marine Phytoplankton. Academic Press, Cambridge.

777 Utermöhl, H., 1958. Zur Vervollkommnung der quantitativen Phytoplankton-Methodik. Mitteilungen - Internationale Vereinigung fuer Theoretische und Angewandte Limnologie 9: $1-38$. 
781 euglenoid flagellates. Critical Reviews in Plant Sciences 7: 303-340. 782 doi:10.1080/07352688809382268.

783 Yamamoto, T., 2003. The Seto Inland Sea - eutrophic or oligotrophic? Marine Pollution $784 \quad$ Bulletin 47: 37-42. doi:10.1016/S0025-326X(02)00416-2. 


\section{Legends}

Fig. 1. Location of the two stations representatives of the Northern Basin (NB) and the Southern Basin (SB) of Biguglia lagoon.

Fig. 2. Relative percentage of the main phytoplankton groups in the two stations (NB and SB) at the three sampling periods. The total abundance (cell. $\left.\mathrm{L}^{-1}\right)$ is specified on the top.

Fig. 3. Abundances of the main potentially mixotrophic protists that contain $\mathrm{Chl} a(+\mathrm{Chl} a)$ in 794 the 10 to $20 \mu \mathrm{m}$ size class (A) and the $>20 \mu \mathrm{m}$ size class (C), or without $\mathrm{Chl} a$ (-Chl $a$ ) in the 10 to $20 \mu \mathrm{m}$ size class (B) and the $>20 \mu \mathrm{m}$ size class (D) at the NB and SB stations of Biguglia lagoon and for the three periods (autumn 2013, spring and summer 2014). Note differences in scales among the four panels.

Fig. 4. Percentages of increase (positive values) or decrease (negative values) of Chl $a$ 800 concentrations during 24-h of in situ incubation in bottles (100* (Chl $\left.\left.a_{\mathrm{T} 24}-\mathrm{Chl} a_{\mathrm{T} 0}\right) / \mathrm{Chl} a_{\mathrm{T} 0}\right)$ : 801 without enrichment (WE), full enrichment (FE), enrichment without $\mathrm{N}(-\mathrm{N})$, enrichment without $\mathrm{P}(-\mathrm{P})$ at the NB and SB stations, respectively, of Biguglia lagoon. Panels represent experimental results for autumn 2013 (A), spring 2014 (B), and summer 2014 (C), respectively.

804 Note differences in scales among the three panels.

805

806 Fig. 5. Abundances of potentially mixotrophic protists containing Chl $a$ (+Chl $a$, light grey 807 bars) or without Chl $a$ (-Chl $a$, black bars) in the 10 to $20 \mu \mathrm{m}$ size class (left panels) and in the 
$>20 \mu \mathrm{m}$ size class (right panels) at the NB and SB stations, respectively, of Biguglia lagoon.

809 Results for the different experiments are represented for autumn 2013 (Top panels, A), spring

8102014 (Middle panels, B), and summer 2014 (Bottom panels C). Different notations along

811 abscissa relate to before the start of the incubation start at T0 (T0), and at T24 i.e. after $24 \mathrm{~h}$

812 incubation respectively for without enrichment (WE), full enrichment (FE), enrichment without

$813 \mathrm{~N}(-\mathrm{N})$ and enrichment without P (-P). Asterisks indicate a significant difference of the value

814 with respect to T0 (grey asterisks, abundance differences for $+\mathrm{Chl} a$ protists; black asterisks,

815 abundance difference for -Chl $a$ protists). Note differences in scales among the six panels.

816

817 Fig. 6. Interaction plots describing the responses of all phytoplankton (total water sample),

818 micro-, nano- and ultraphytoplankton to factorial addition of enrichment with $\mathrm{N}$ and/or $\mathrm{P}$ at the

819 two NB and SB stations of Biguglia lagoon in (A) autumn 2013, (B) spring, and (C) summer

820 2014. Dashed line represents N addition (without enrichment - enrichment minus P), the solid

821 line represents $\mathrm{P}$ addition (enrichment minus $\mathrm{N}$ - full enrichment). The $\mathrm{Y}$-axis represents the

822 biomass responses to the factorial addition of $\mathrm{N}$ and/or $\mathrm{P}$ relative to the bottles without

823 enrichment. Trends allow hypothesizing about the co-limitation type (simultaneous,

824 independent, serial and synergistic limitation), the negative response, and the absence of

825 response to nutrient addition (Harpole et al., 2011). Note the scale differences.

827 Fig. 7. Estimated contribution of internal (black bars), external (light grey bars) and recycled

828 (dark grey bars) N (left panels) and P (right panels) pools to the potential increments in Chl $a$

829 stocks during the $24 \mathrm{~h}$ incubation without $\mathrm{N}$ (left panels) or $\mathrm{P}$ (right panels) enrichment for the

830 total phytoplankton (total) and the micro-, nano- and ultraphytoplankton at the two stations of

831 Biguglia lagoon in autumn 2013, spring 2014 and summer 2014. Note the scale differences. 
833 Fig. 8. Mortality rates (g) as a function of the maximum growth rates ( $\mu$ max) of autotrophic 834 planktonic communities at the NB and SB stations [total phytoplankton (t), micro- (m), nano835 (n), and ultraphytoplankton (u)] in bioassays performed in autumn 2013, spring and summer 836 2014. The line indicates the $g: \mu_{\max }$ ratio $=1$. 


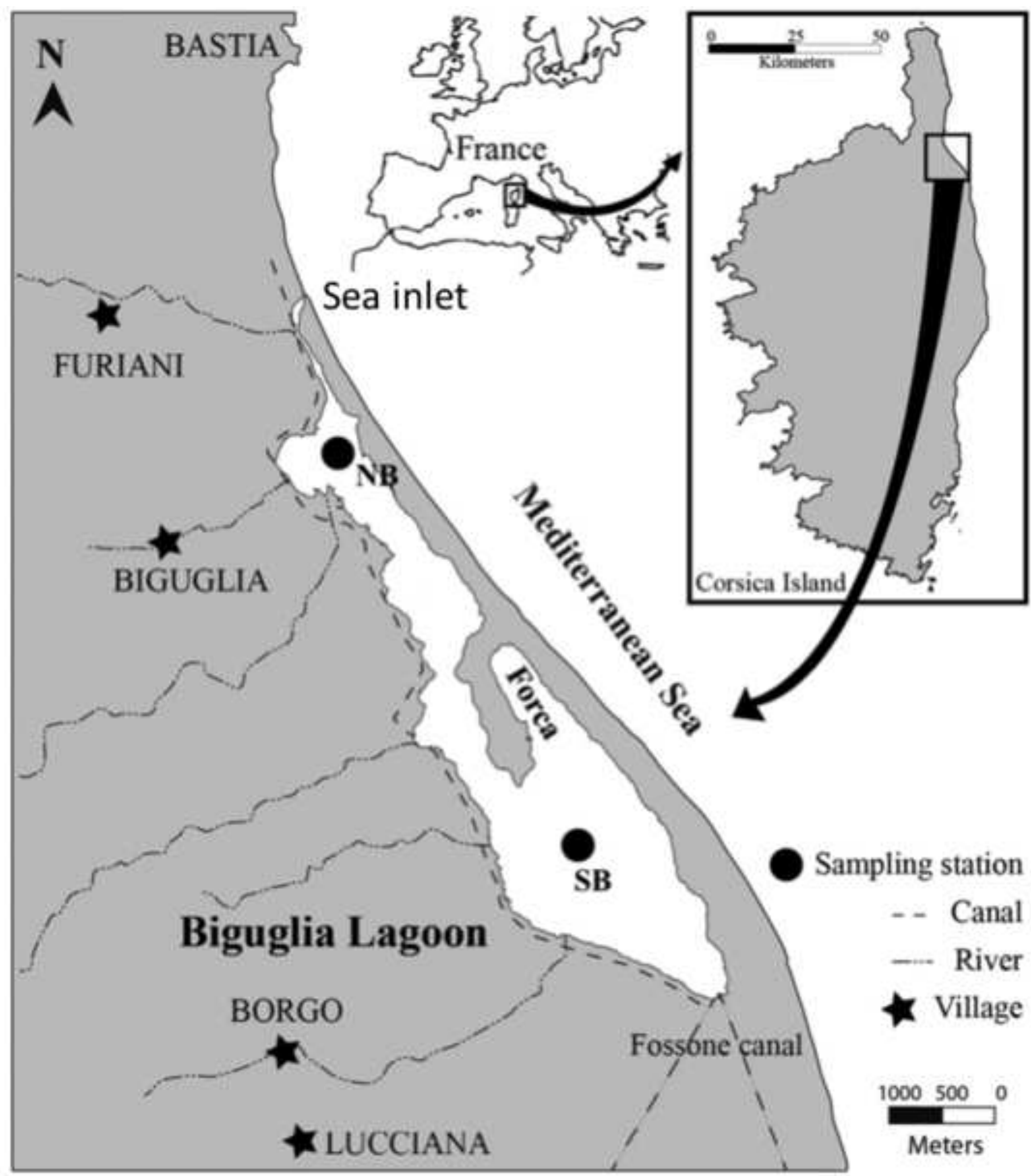




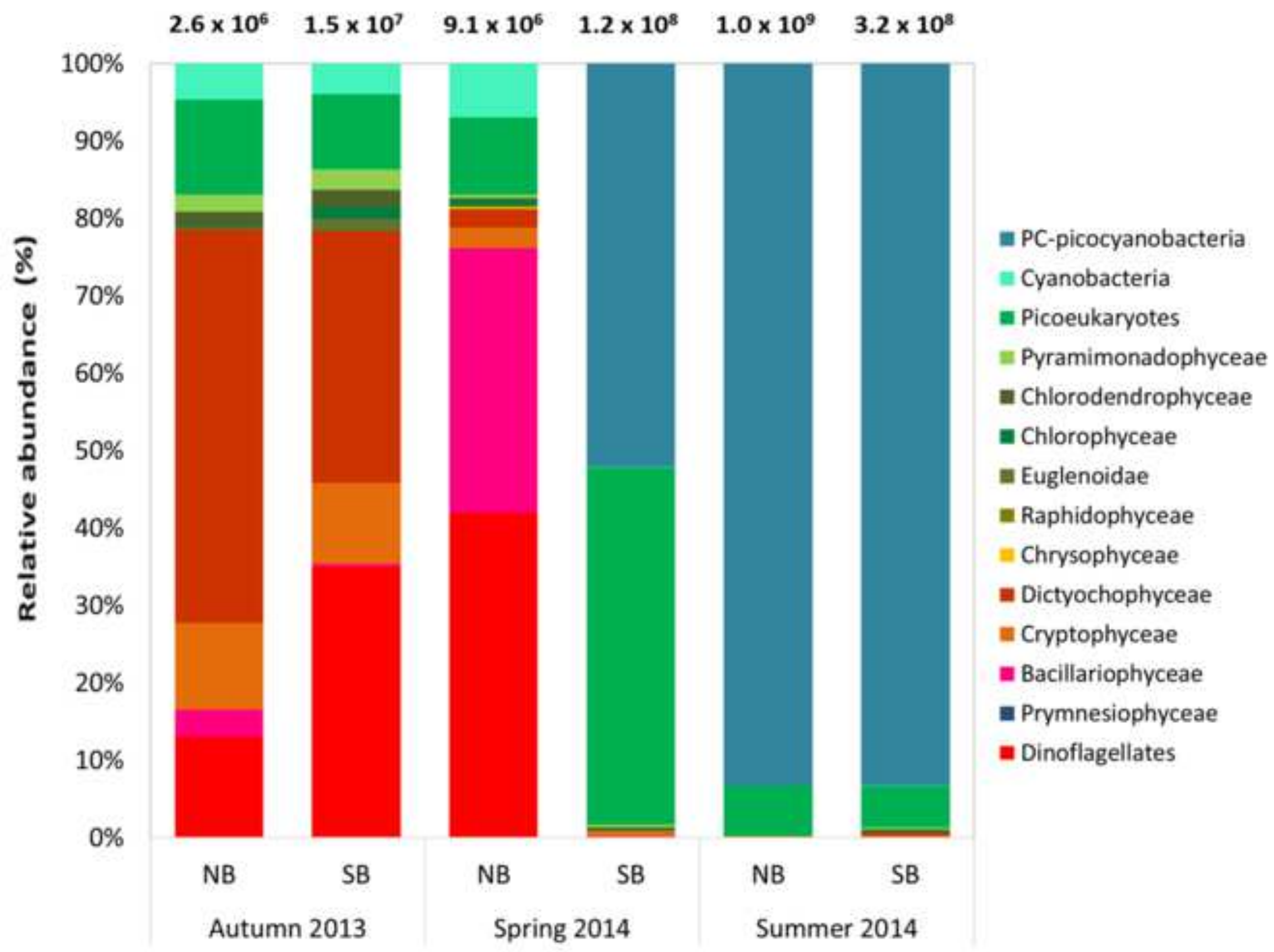




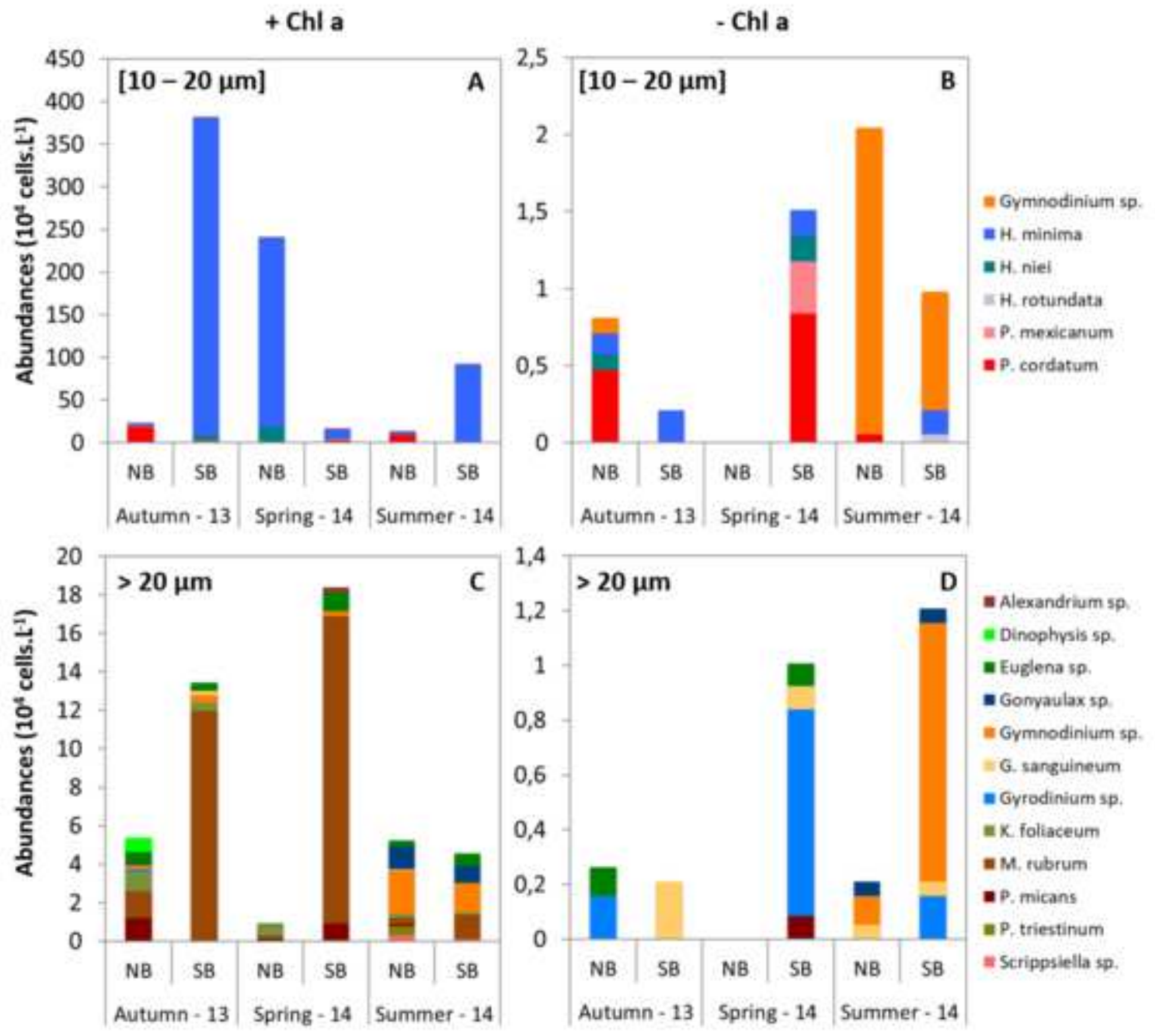



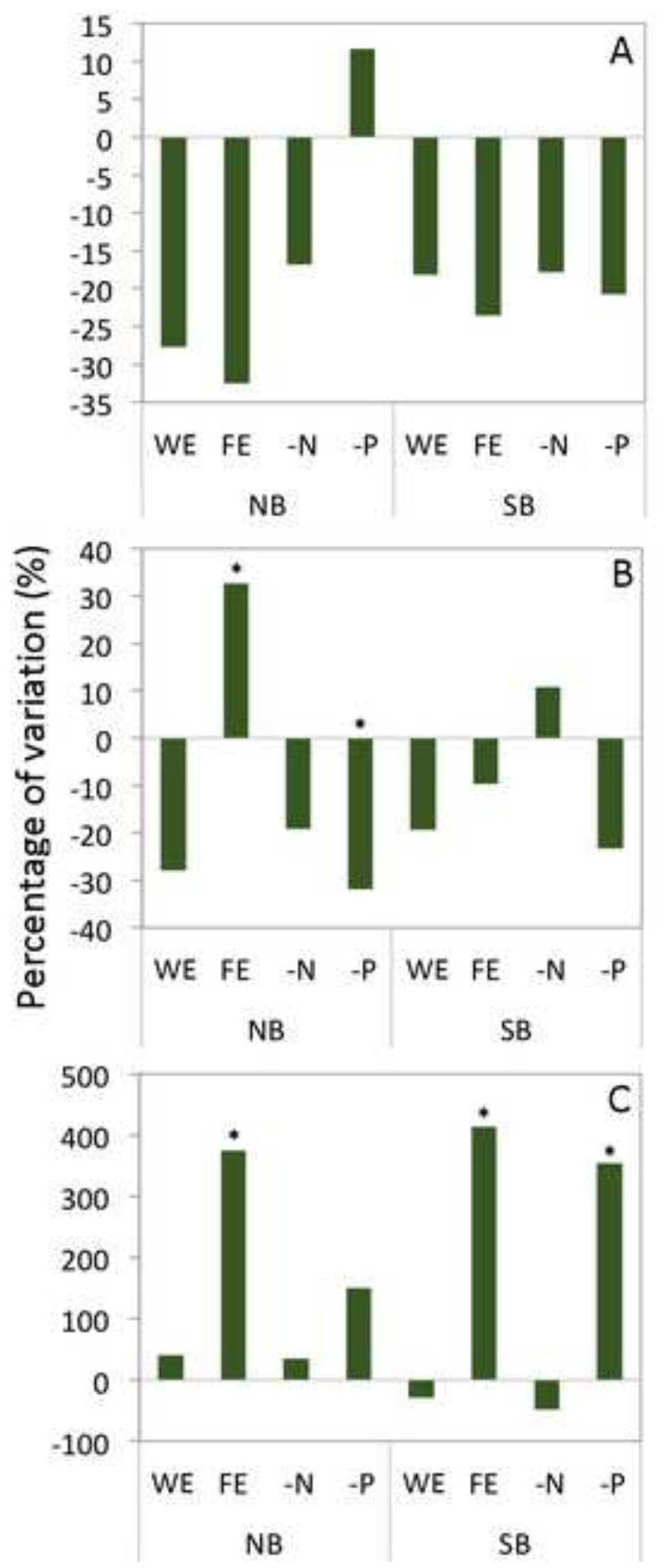

Chl a concentration 


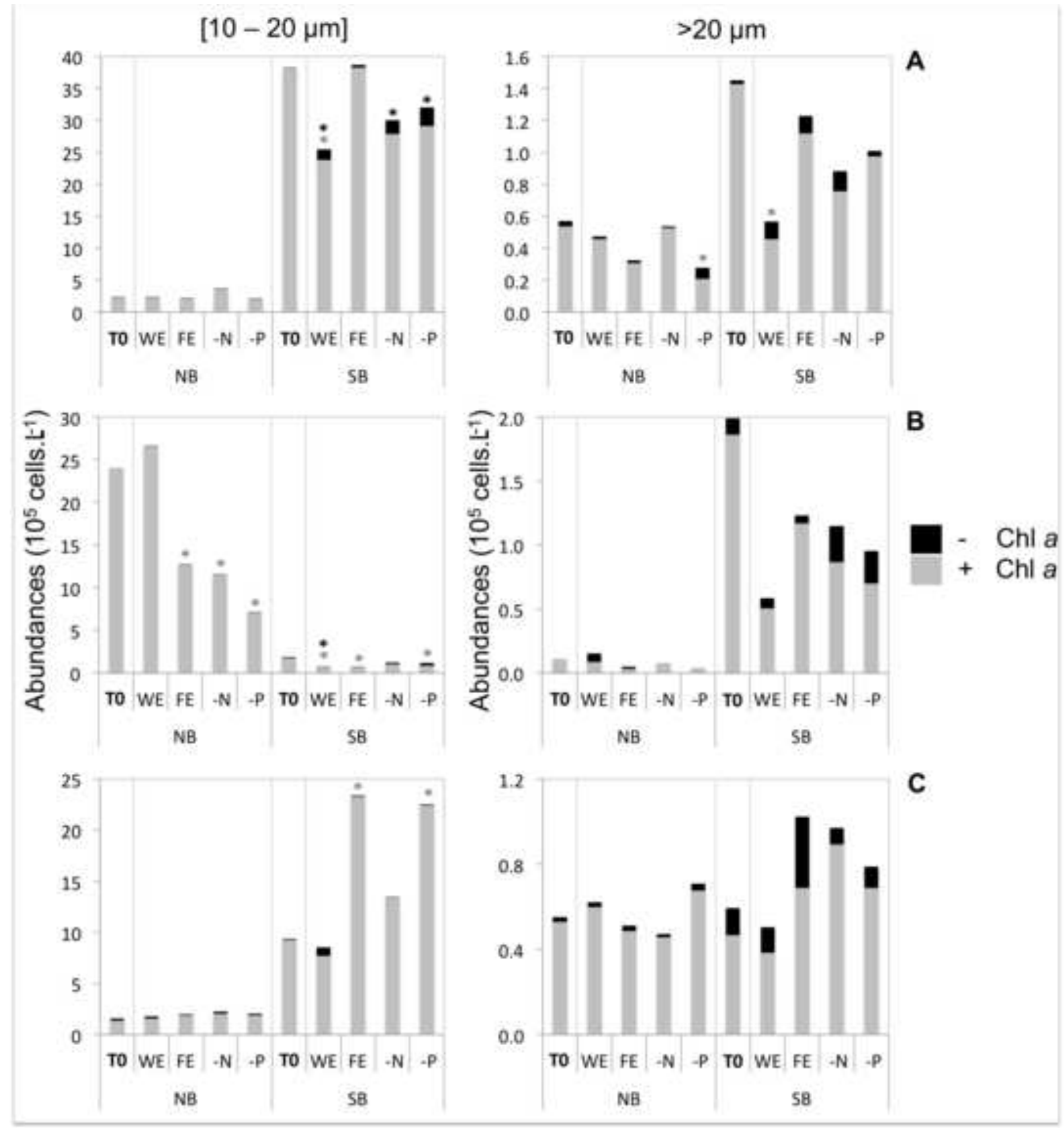


Click here to access/download;Figure;Figure 6.tif $\underline{\underline{ }}$

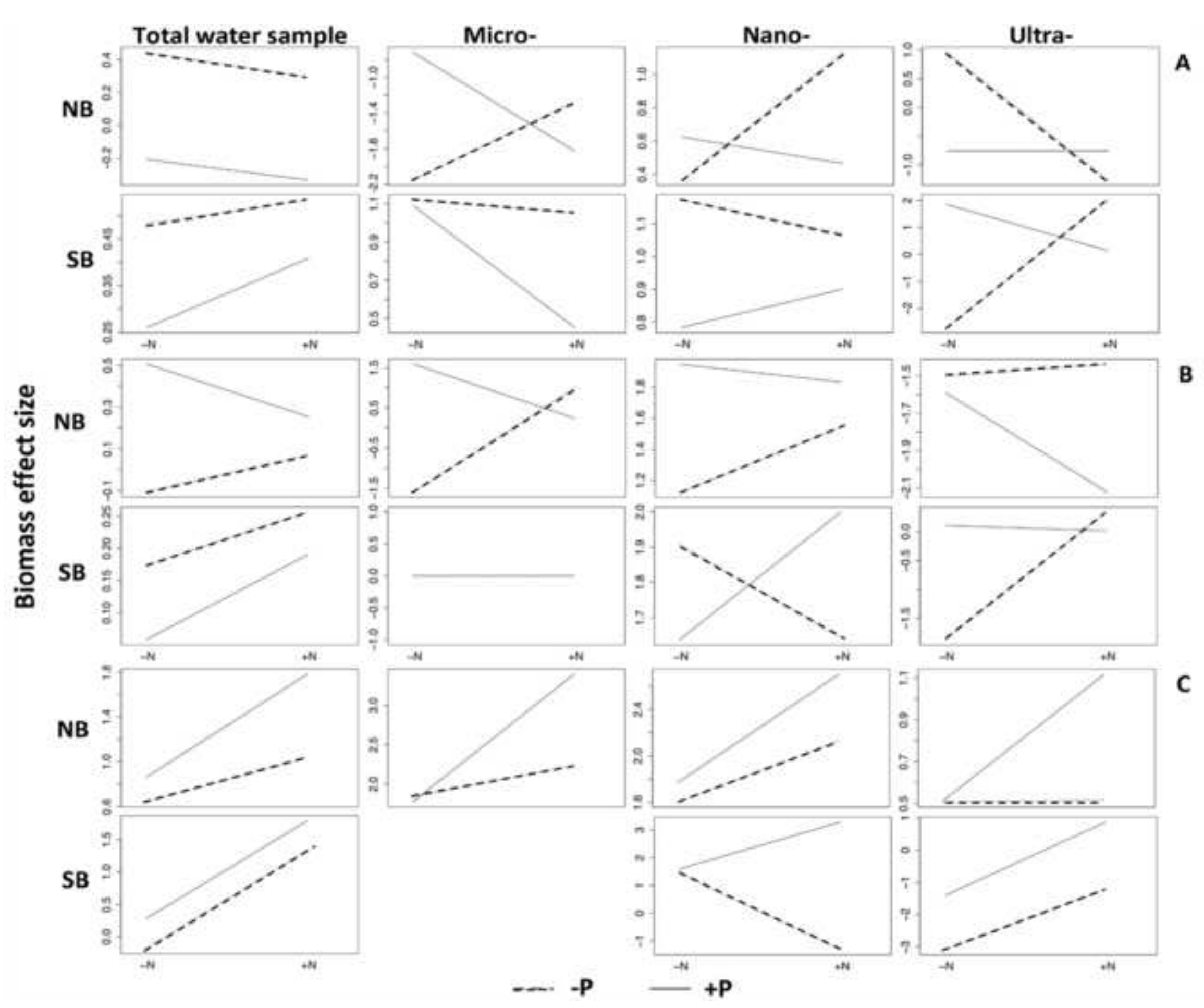

c


$\mu \mathrm{g} \mathrm{Chl} \mathrm{a.} \mathrm{L^{-1 }}$

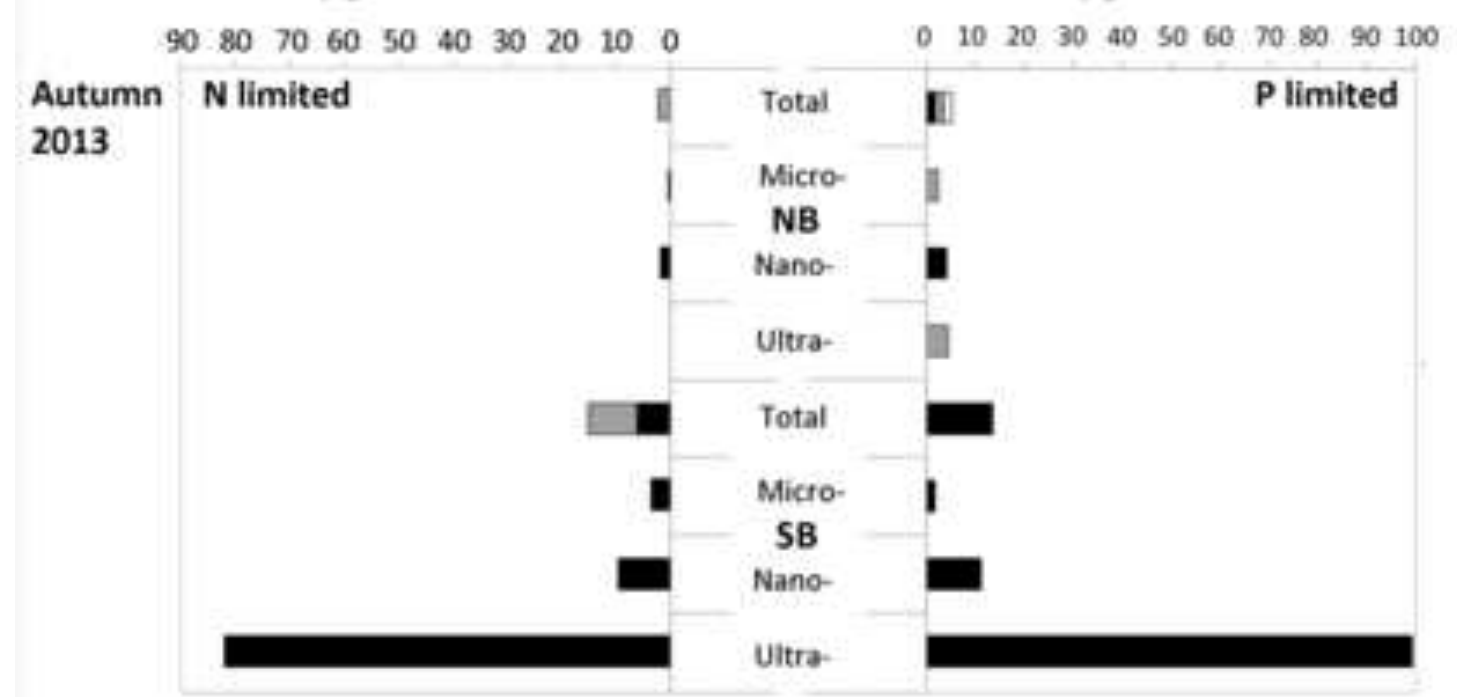

Spring

2014

$\begin{array}{lllllllll}8 & 7 & 6 & 5 & 4 & 3 & 2 & 1 & 0\end{array}$

Hg Chl a. L-1

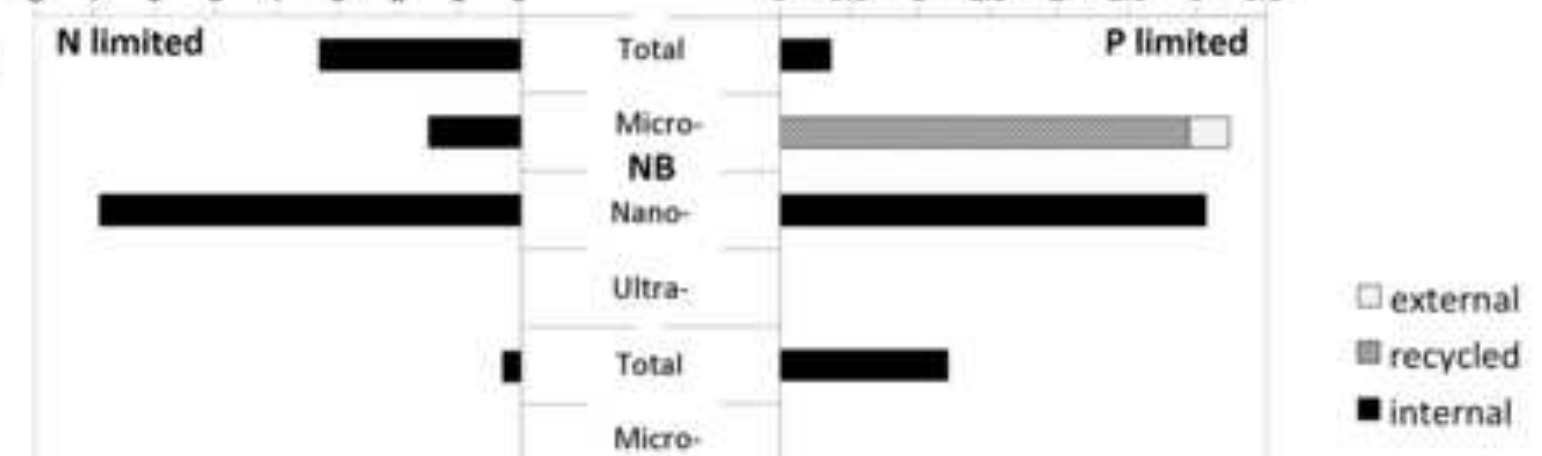

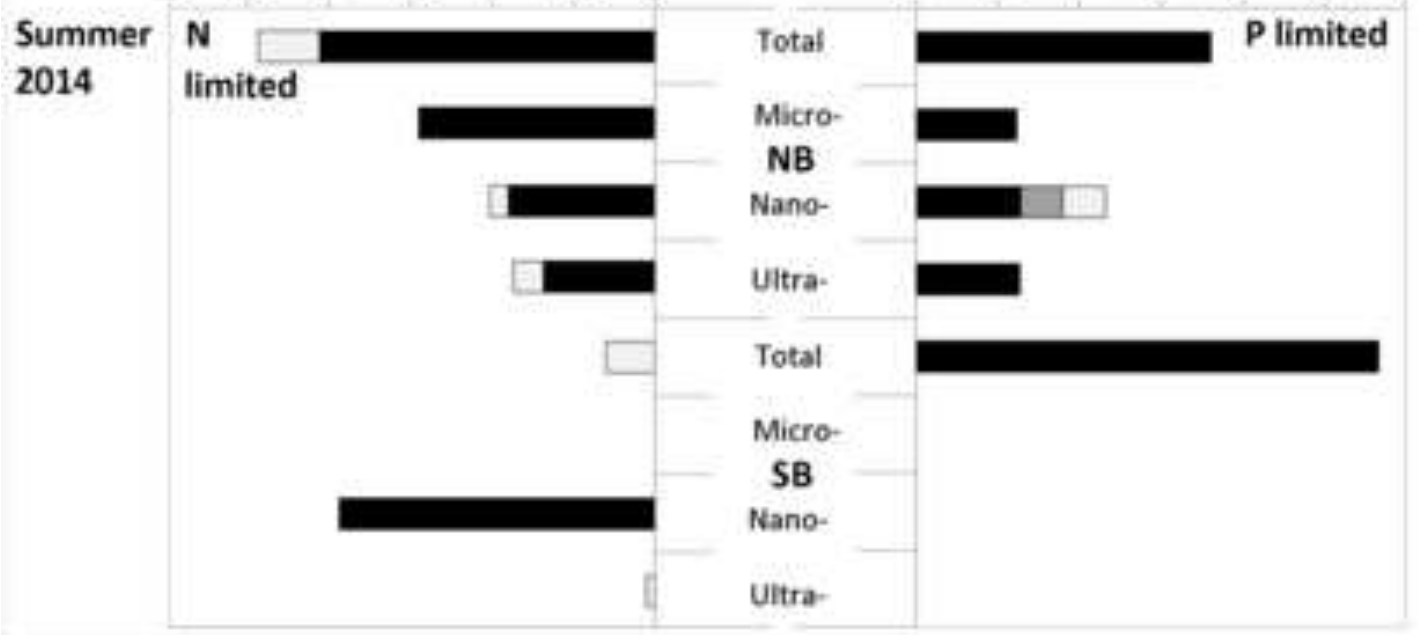




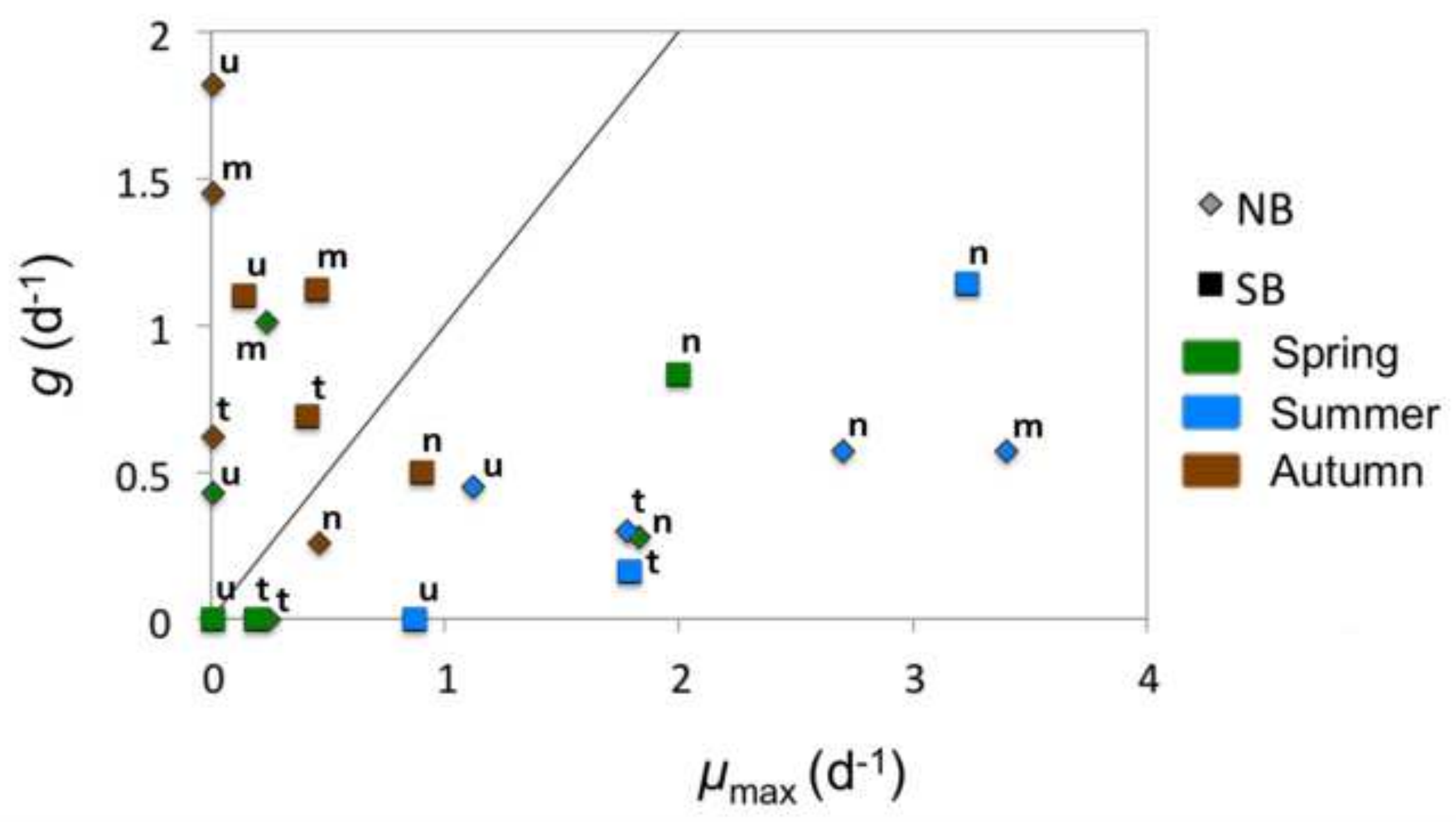




\section{Table}

2

3 Table 1. Nutrient concentrations, mean Chlorophyll $a(\mathrm{Chl} a)$ concentrations, and percentages

4 of the total Chl $a$ concentrations represented by microphytoplankton $>20 \mu \mathrm{m}$ in size (Micro),

5 nanophytoplankton between 5 and $20 \mu \mathrm{m}$ in size (Nano) and ultraphytoplankton $<5 \mu \mathrm{m}$ in size

6 (Ultra) in the two stations (NB and SB) of Biguglia lagoon for the three samplings. DIN:

7 Dissolved inorganic nitrogen, DIP: Dissolved inorganic phosphorus.

8

\begin{tabular}{|c|c|c|c|c|c|c|c|c|c|c|}
\hline \multirow[t]{2}{*}{ Date of sampling } & \multirow[t]{2}{*}{ Station } & $\mathrm{NH}_{4}{ }^{+}$ & $\mathrm{NO}_{3}^{-}$ & $\mathrm{NO}_{2}^{-}$ & $\mathrm{PO}_{4}{ }^{3-}$ & \multirow[t]{2}{*}{ DIN:DIP } & \multirow{2}{*}{$\begin{array}{c}\text { Chl } a \pm \text { SD } \\
\left(\mu \mathrm{g} \underline{\operatorname{Ll}}^{-1}\right)\end{array}$} & \multirow[t]{2}{*}{ Micro } & \multirow{2}{*}{$\begin{array}{c}\text { Nano } \\
(\%)\end{array}$} & \multirow[t]{2}{*}{ Ultra } \\
\hline & & \multicolumn{4}{|c|}{$(\mu \mathrm{M})$} & & & & & \\
\hline $26 / 11 / 2013$ & NB & 7.52 & 70.01 & 0.49 & 0.73 & 107.29 & $5.41 \pm 0.26$ & 26.5 & 39.8 & 33.7 \\
\hline $04 / 12 / 2013$ & SB & 0.69 & 40.72 & 0.29 & 0.64 & 65.52 & $20.60 \pm 2.93$ & 17.1 & 25.3 & 57.5 \\
\hline 07/04/2014 & NB & 2.18 & 17.47 & 0.16 & 0.16 & 124.47 & $5.75 \pm 0.29$ & 15.9 & 14.6 & 69.5 \\
\hline $02 / 04 / 2014$ & SB & 1.85 & 93.22 & 0.30 & 0.00 & - & $5.06 \pm 0.41$ & 39.5 & 11.9 & 48.7 \\
\hline $11 / 09 / 2014$ & NB & 0.37 & 0.03 & 0.00 & 0.03 & 13.33 & $3.78 \pm 0.06$ & 7.5 & 9.2 & 83.3 \\
\hline 09/09/2014 & SB & 1.24 & 0.11 & 0.09 & 0.11 & 13.06 & $3.62 \pm 0.11$ & 0.1 & 11.9 & 88.0 \\
\hline
\end{tabular}

9 